Guilherme Madeira Dezem

\title{
A FlexibilizaÇÃo no Processo Penal
}

\author{
TESE DE DOUTORADO
}

Orientador Professor Titular Antonio Scarance Fernandes

FACULDADE DE DIREITO DA UNIVERSIDADE DE SÃO PAULO 


\section{Guilherme Madeira Dezem}

\section{A Flexibilização no Processo Penal}

Tese apresentada à Faculdade de Direito da Universidade de São Paulo, como exigência para obtenção do título de Doutor em Direito Processual, pelo Programa de Pós-Graduação em Direito - Área de Concentração em Direito Processual, sob a orientação do Professor Titular Antonio Scarance Fernandes

FACULDADE DE DIREITO DA UNIVERSIDADE DE SÃO PAULO

SÃO PAULO, 2013 


\section{AGRADECIMENTOS}

Muitas foram as pessoas que me ajudaram no desenvolvimento deste trabalho. Seria vã a tentativa de nomear cada uma destas pessoas aqui tamanha a ajuda que recebi dos amigos.

Por isso eu decidi concentrar estes agradecimentos em duas pessoas que representam para mim tudo aquilo que alguém pode desejar na vida.

Em primeiro lugar o agradecimento é para Deus. Eu tenho certeza que Ele, em sua sabedoria, abre caminhos e também fecha aqueles com resultados ruins. Deus que em sua infinita sabedoria me testou, de diversas formas, nesta jornada de forma a me fazer aprender importantes lições. Acima de tudo, a lição que eu mais aprendi com Deus nesta jornada foram as lições da humanidade e do amor. Quanto mais próximos de Deus mais humanos nos tornamos e, quanto mais humanos, também mais próximos de Deus ficamos.

Também sou grato a Deus por ter colocado em meu caminho a segunda pessoa a quem agradeço por esta tese, o Professor Antonio Scarance Fernandes.

Conheço o Professor Scarance desde 1997, ocasião em que fui seu orientado em bolsa de pesquisa da FAPESP e, depois, tornei-me seu funcionário no ASF, curso preparatório chefiado por ele e por sua esposa, Dra. Sueli Diez Fernandes.

O Professor, como todos nós o chamamos, foi meu chefe, meu orientador no Mestrado e Doutorado, meu padrinho de casamento, mas, acima de tudo, foi a pessoa que salvou a minha vida, por duas vezes.

Quando era seu funcionário no ASF minha mãe faleceu e posso dizer, sem nenhuma dúvida, que se não fosse o apoio do Professor e da sua esposa eu não estaria aqui hoje.

Mais recentemente minha vida foi salva pelo Professor pela segunda vez. Sem a sua necessária intervenção e orientação esta Tese não teria sido sequer entregue ao departamento.

Foi a intervenção do Professor que fez o trabalho evoluir e alterar seu patamar. Sem sombra de dúvidas e sem falsa modéstia eu digo: todos os acertos desta tese são 
devidos única e exclusivamente ao Professor Scarance, todos os erros e imperfeições devem-se unicamente a mim.

No Talmud está escrito: "Quem salva uma vida salva o mundo inteiro". O Professor Scarance salvou o mundo, pelo menos duas vezes.

Obrigado Professor Scarance, sem o senhor eu não seria quem sou. 
“Eu vejo um novo começo de era

De gente fina, elegante e sincera

Com habilidade pra dizer mais sim do que não."

(Lulu Santos, Tempos Modernos) 
Para a minha padawan, Milena.

Que sua vida seja cheia de magia. 


\section{RESUMO}

A liquidez na pós-modernidade tem gerado a flexibilidade da vida contemporânea, causando transformações arrebatadoras na vida do indivíduo e na forma como ele se relaciona com os outros e com o mundo.

Estas transformações são cada vez mais velozes, o que gera dificuldade para o legislador, pois não consegue regular todas estas novas relações criadas, de modo a comprometer a efetividade do processo e também as suas garantias.

Diante destas dificuldades e das múltiplas peculiaridades que os casos concretos impõem, há necessidade de abandono de padrões rígidos da aplicação da legislação permitindo sua flexibilização.

Daí surge a ideia de flexibilização do processo, como sendo a adaptação das normas às peculiaridades do caso concreto. Esta flexibilização deve ser pautada por parâmetros para que não se resvale no arbítrio e na insegurança jurídica.

Os critérios desenvolvidos para a flexibilização do processo permitem, ao mesmo tempo, que ele seja mais justo e também mais eficaz, sem que com isso sejam quebradas as garantias do devido processo legal.

A partir da elaboração de uma teoria geral da flexibilização com indicação de parâmetros para a sua implementação, examina-se esta teoria em diversos institutos do direito processual penal a fim de validá-la.

São analisados institutos relativos às medidas cautelares pessoais, provas, procedimento e cooperação jurídica internacional como forma de validação da teoria geral anteriormente desenvolvida. 


\section{RIASSUNTO}

Liquidità in postmodernità ha generato la flessibilità della vita contemporanea, causando cambiamenti radicali nella propria vita e come si relaziona con gli altri e con il mondo.

Queste trasformazioni sono sempre più veloci, che crea difficoltà per il legislatore, perché non può regolare tutti questi nuovi rapporti creati per compromettere l'efficacia del processo e le garanzie.

Date queste difficoltà e le peculiarità dei molti casi reali impongono alcuna necessità di abbandonare i rigidi standard di applicazione che consente la sua flessibilità.

Da qui l'idea di facilitare il processo, come l'adeguamento delle peculiarità del caso di specie. Tale flessibilità deve essere guidata da parametri affinché non sono resvale la volontà e l'incertezza giuridica.

I criteri sviluppato per consentire il processo di rilassamento, mentre è anche più equa ed efficace, senza che venga rotto con le garanzie del giusto processo.

Dallo sviluppo di una teoria generale di rilassamento che indica i parametri per la sua attuazione, esamina questa teoria in diversi istituti di diritto di procedura penale, al fine di convalidarlo.

Vengono analizzati gli istituti in materia di misure di protezione personale, prove, procedure e cooperazione giudiziaria internazionale come strumento di validazione della teoria generale sviluppato in precedenza. 


\begin{abstract}
Liquidity in postmodernity has generated the flexibility of contemporary life, causing sweeping changes in one's life and how he relates to others and to the world.

These transformations are becoming faster, which creates difficulty for the legislature because it can not regulate all these new relationships created in order to compromise the effectiveness of the process and its guarantees.

Given these difficulties and the many peculiarities that actual cases impose no need to abandon the rigid standards of enforcement allowing its flexibility.

Hence the idea of easing the process, as the adaptation of the peculiarities of the case. This flexibility should be guided by parameters that are not resvale the will and the legal uncertainty.

The criteria developed to allow the relaxation process, while it is also fairer and more effective without it being broken with the guarantees of due process.

From the development of a general theory of relaxation indicating parameters for its implementation, examines this theory in several institutes of criminal procedural law in order to validate it.

Are analyzed institutes relating to personal protective measures, evidence, procedure and international legal cooperation as a means of validation of the general theory developed previously.
\end{abstract}




\section{SUMÁRIO}

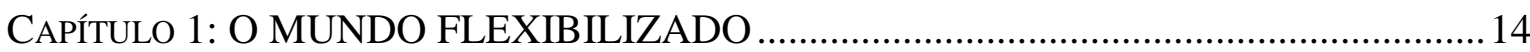

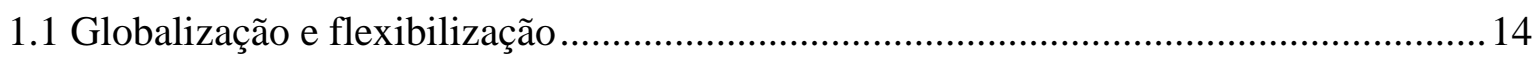

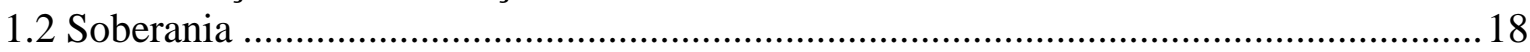

1.2.1 - Soberania e flexibilização: a mudança de paradigmas ............................................2 20

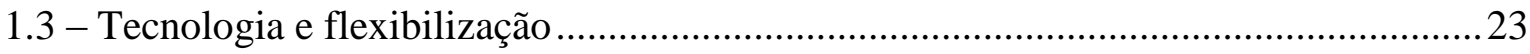

1.4 - O processo no mundo pautado pela flexibilização ...................................................26

CAPÍTULO 2: FLEXIBILIZAÇÃO

2.1 - O sentido léxico do termo flexibilização

2.2 - A noção de flexibilização no processo

2.3 - Os sistemas rígidos e os sistemas flexíveis no Direito processual penal

2.4 - O caminhar do processo penal brasileiro para a flexibilização

2.5 - Flexibilização em sentido amplo e em sentido estrito: regra de exceção, interpretação extensiva e equidade

2.6 - Planos de flexibilização

2.7 - Os parâmetros para a flexibilização em sentido estrito

2.7.1 - Flexibilização e legalidade

2.7.2 - Flexibilização e proporcionalidade

2.7.2.1 - O princípio da proporcionalidade como parâmetro da flexibilização nos hard cases

2.7.3 - Flexibilização e razoabilidade

2.8 - A operação de flexibilização

2.8.1 - A flexibilização e as partes

CAPÍTULO 3: DIREITOS HUMANOS, DEVIDO PROCESSO LEGAL E FLEXIBILIZAÇÃO

3.1 - Considerações iniciais

3.2 - Caraterísticas dos direitos fundamentais

3.3 - Respeito aos direitos humanos e flexibilização

3.4 - Os direitos humanos e as Convenções

3.5 - Direito Internacional dos Direitos Humanos e flexibilização

3.5.1 - Devido processo legal na visão da Corte Interamericana de Direitos Humanos

3.6 - Direitos humanos, devido processo legal, flexibilização e a macro-criminalidade

CAPÍTULO 4: MEDIDAS CAUTELARES PESSOAIS E FLEXIBILIZAÇÃO

4.1 - Flexibilixação legislativa: parâmetros de razoabilidade e proporcionalidade nas medidas cautelares pessoais

4.1.1 - Flexibilização legislativa dirigida ao juiz e motivação

4.3 - Flexibilização e cumulação das medidas cautelares

4.3.1 - Flexibilização judicial, cumulação de medidas cautelares e prisão preventiva

4.4 - Flexibilização judicial e prisão em flagrante

4.5 - Flexibilização e Prisão Preventiva - Descumprimento de medidas cautelares pessoais

4.6 - Flexibilização e medidas cautelares diversas da prisão: Noções gerais

4.7 - Flexibilização judicial das medidas cautelares diversas da prisão: Determinações e proibições de comparecimento

4.8 - Flexibilização judicial e suspensão da função pública

4.9 - Prisão domiciliar: Medida substitutiva da prisão preventiva

CAPÍTULO 5: FLEXIBILIZAÇÃO DO PROCESSO: PROCEDIMENTO E PROVAS

5.1 - Resposta à acusação: flexibilização do prazo e do momento para arrolar testemunhas

5.2 - Videoconferência: flexibilização de sua utilização 
5.3 - Prazo dos memoriais no procedimento comum e flexibilização

5.4 - Flexibilização, prova e meios virtuais

5.5 - O uso do Recurso em Sentido Estrito para hipóteses não previstas em lei como forma de flexibilização em sentido amplo

CAPÍTULO 6: FLEXIBILIZAÇÃO E COOPERAÇÃO JURÍDICA INTERNACIONAL

6.1 - O dever constitucional de cooperação

6.2 - Formas de cooperação: Carta Rogatória

6.2.1 - Noção e abrangência

6.3 - Flexibilização na cooperação: $\mathrm{O}$ auxílio direto

6.4 - Limitações à cooperação jurídica internacional

6.4.1 - A solução norte americana e a teoria do non inquiry

6.4.2 - A solução espanhola e a STC 91/2000

6.4.3 - A solução brasileira - posição do STF e do STJ: análise geral dos requisitos para a concessão do exequatur

6.5 - Flexibilização do processo: a proposta de paradigma para a cooperação jurídica

CONCLUSÃO

REFERÊNCIAS BIBLIOGRÁFICAS 42 


\section{INTRODUÇÃO}

O mundo está em processo constante de transformação e, hoje em dia, este processo mostra-se ainda mais acentuado. $\mathrm{O}$ aumento da velocidade das mudanças está sem precedentes na história da humanidade.

As cotidianas transformações estão tão rápidas que geram dificuldades para o legislador regulá-las com a necessária eficiência e, no entanto, há necessidade do estabelecimento de padrões normativos para a solução das questões jurídicas que surgem com estas mudanças, sem, contudo, que haja desrespeito aos direitos humanos.

O objetivo do trabalho consistirá na demonstração de que a flexibilização do processo é o mecanismo que atende às transformações de maneira a assegurar tanto a eficiência do sistema quanto o garantismo.

Para isto, o trabalho será dividido em duas partes. Na primeira parte procurarse-á demonstrar quais são os parâmetros para a flexibilização do processo e, na segunda, estes parâmetros apresentados serão aplicados em diversos institutos para a demonstração de sua validade.

A adoção deste método de trabalho justificar-se-á na medida em que a construção da teoria deve preceder ao seu teste. Somente com a aplicação da teoria desenvolvida é que poderá ser comprovada sua eficácia no trato das questões jurídicas.

Assim, o Capítulo 1 demonstrará o caminhar do mundo para a flexibilização, analisando-se alguns importantes tópicos: a globalização, a soberania e a tecnologia, terminando por analisar as implicações destas flexibilizações no processo penal.

No Capítulo 2 será desenvolvida a teoria da flexibilização. Aqui serão indicados os parâmetros para que ela ocorra bem como qual deve ser a operação do juiz na efetivação deste processo.

No Capítulo 3 mostrar-se-á a relação existente entre a flexibilização do processo, os direitos humanos e o devido processo legal; demonstrando que a 
flexibilização não pode violar os direitos humanos e que ela não se mostra incompatível com o devido processo legal, mostrando-se como exigência dele.

Superada a primeira parte com a construção da teoria, passar-se-á a desenvolver a segunda parte com sua aplicação em diversos institutos processuais.

No Capítulo 4 a teoria da flexibilização será aplicada ao tema das medidas cautelares pessoais. Procurar-se-á demonstrar como a flexibilização do processo pode ajudar na solução equilibrada de importantes controvérsias existentes na lei.

No Capítulo 5 será analisada a flexibilização do processo em relação ao tema do procedimento e das provas. Aqui será demonstrado como o mecanismo da flexibilização pode resolver peculiaridades do caso concreto e ajudar na solução do tema da prova no meio virtual.

No Capítulo 6 a flexibilização do processo será aplicada ao tema da cooperação jurídica internacional. Aqui demonstrar-se-á a necessidade de ser superado o paradigma da desconfiança entre os Estados para que se caminhe em direção ao paradigma da confiança na cooperação, e a flexibilização ajudará neste processo de harmonização.

A linha de pesquisa consiste na tentativa de compatibilização da proteção dos direitos humanos com a eficiência do sistema. A flexibilização mostrar-se-á, então, como importante mecanismo nesta composição. 


\section{CAPÍTULO 1: O MUNDO FLEXIBILIZADO}

O mundo tem passado por várias e acentuadas mudanças nos últimos tempos, indicativas de um caminhar no sentido da flexibilização. Estas mudanças abrangem os diversos aspectos da sociedade, desde mudanças comportamentais dos indivíduos, até mesmo mudanças na própria estrutura organizacional do Estado.

A flexibilização, como fenômeno social, embora manifeste-se em muitos campos, merece ser destacada para o presente trabalho em alguns aspectos. Assim, podem ser destacadas a globalização, a soberania e a tecnologia.

A globalização incrementa a relação entre os países, produz aumento da cooperação jurídica e, por isso, gera fluidez nos sistemas jurídicos. A globalização produz aquilo que se chamou de Unsicherheit e que afasta a previsibilidade que estamos acostumados.

O conceito de soberania passa por revisão devido a vários motivos como, por exemplo, a atuação dos Tribunais Internacionais de Direitos Humanos ou pela necessidade de Cooperação Jurídica Internacional.

O avanço tecnológico atual, notadamente com a internet, torna a vida mais fluida, pois aumenta sensivelmente a velocidade da comunicação.

\subsection{Globalização e flexibilização}


ANTHONY GIDDENS começa sua explicação sobre o mundo moderno com um passeio ao supermercado ${ }^{1}$. A inusitada metáfora é perfeita para que sejam entendidos os múltiplos significados e implicações da globalização.

Quando se passeia hoje em um supermercado, em cada prateleira percebe-se um pedaço do mundo: em um canto podem ser comprados chás produzidos na Índia, em outro são encontradas salsichas alemãs. Caminhando-se um pouco mais podem ser encontrados diversos produtos chineses e também carnes argentinas.

Ora, este singelo passeio nos permite inferir a característica marcante da modernidade e que acaba por ser uma das principais tônicas de toda e qualquer tentativa de se ler o mundo atual: a globalização ${ }^{2}$.

Embora vista por alguns como fenômeno estritamente econômico, o sentido da globalização é mais amplo: abarca tanto fenômeno econômico quanto fenômeno cultural ${ }^{3}$.

A pós-modernidade ${ }^{4}$ acaba por trazer fatores que contribuem para a globalização e ampliam sua incidência. Exemplo disto é a integração virtual entre as economias e as próprias pessoas dos diversos países do mundo ${ }^{5}$.

\footnotetext{
${ }^{1}$ GIDDENS, Anthony. Sociologia. 4. ed. Porto Alegre: Artmed, 2005.

${ }^{2}$ Para GIDDENS globalização é termo utilizado para referir-se "àqueles processos que estão intensificando as relações a interdependência sociais globais" (GIDDENS, Anthony. Op. cit., p. 61).

${ }^{3}$ Novamente nos valemos aqui de GIDDENS: "Embora as forças econômicas sejam uma parte integrante da globalização, seria errado sugerir que elas sozinhas a produzam. A globalização é criada pela convergência de fatores políticos, sociais, culturais e econômicos. Foi impelida, sobretudo, pelo desenvolvimento de tecnologias da informação e da comunicação que intensificam a velocidade e o alcance da interação entre as pessoas ao redor do mundo" (Idem, ibidem).

${ }^{4} \mathrm{O}$ conceito de pós-modernidade é um dos mais discutidos em toda a Sociologia. Há até mesmo quem negue o estado da pós-modernidade. Nos limites deste trabalho importa esclarecer que é adotado o conceito de pósmodernismo de DAVID HARVEY, que esclarece “(...) o pós-modernismo, com sua ênfase na efemeridade da jouissance, sua insistência na impenetrabilidade do outro, sua concentração antes no texto do que na obra, sua inclinação pela desconstrução que beira o niilismo, sua preferencia pela estética, em vez da ética, leva as coisas longes demais. Ele as conduz para além do ponto em que acaba a política coerente, enquanto a corrente que busca uma acomodação pacífica com o mercado o envereda firmemente pelo caminho de uma cultura empreendimentista que é o marco do neoconservadorismo reacionário. Os filósofos pós-modernos nos dizem que não apenas aceitemos mas até nos entreguemos às fragmentações e à cacofonia de vozes por meio das quais os dilemas do mundo moderno são compreendidos." HaRveY, David. Condição pósmoderna. 7. ed. São Paulo: Edições Loyola, 1998. p. 111-112.

Já no campo do Direito, é de se destacar o trabalho desenvolvido por EDUARDo BITTAR ao buscar os paradigmas da pós-modernidade. Após destacar que a pós-modernidade é conceito que se choca com a modernidade em alguns setores, pois estamos em fase ainda de transição, afirma Bittar, com base em Harvey, "a vinda do pluralismo, inaugurado na pós-modernidade, é saudada por uns com muito otimismo, e, por outros, com muito pessimismo. Em lugar do uno, o diviso; em lugar do total, o fragmentário; em lugar do certo, o indeterminado; em lugar do universal, o local; em lugar do despersonificado, o personalíssimo". BITTAR, Eduardo C. B. O direito na pós-modernidade (e reflexões frankfurtianas). 2. ed. atual. e ampl. Rio de Janeiro: Forense Universitária, 2009. p. 167.
} 
O aumento deste intercâmbio de pessoas e bens afeta as relações jurídicas e os sistemas jurídicos na medida em que pessoas de diversas nacionalidades serão regidas por leis que não são as leis de seus países de origem.

Além disto, outras mudanças provocam implemento da globalização. O surgimento de novos atores como organizações intergovernamentais e por organizações não-governamentais também acaba por ampliar o âmbito das relações entre Estados e pessoas $^{6}$. Isso porque a atuação destas organizações hoje não é mais restrita unicamente ao seu Estado de origem e, assim como as pessoas, as organizações também tem atuação internacional.

Todo este processo de globalização torna, certamente, o mundo mais inseguro, fazendo com que a Unsicherheit seja característica do nosso tempo ${ }^{7}$. Aqui o termo Unsicherheit vem da língua alemã e significa mais do que mera insegurança.

Como explica ZYGMUNT BAUMAN, Unsicherheit significa “(...) um desconforto muito mais complexo, que inclui a incerteza, a falta de proteção e a insegurança (...)”. O sentido de ordem que se tinha em épocas anteriores se perde na pós-modernidade.

Novamente ZYGMUNT BAUMAN afirma:

\begin{abstract}
"as coisas estão em ordem se você não precisa se preocupar com a ordem das coisas; as coisas estão em ordem se você não pensar, ou não sentir a necessidade de pensar, na ordem como um problema, muito menos como uma tarefa. E uma vez que você começa a pensar na ordem, isso é sinal de que algo em algum lugar está fora de ordem, de que as coisas estão escapando de suas mãos, e por isso você deve tomar alguma atitude para colocá-las outra vez na linha." 8
\end{abstract}

\footnotetext{
${ }^{5}$ GIDDENS, Anthony. Op. cit., p. 62.

${ }^{6}$ GIDDENS afirma este aspecto: "finalmente, a globalização está sendo conduzida pelas organizações intergovernamentais (OIGs) e pelas organizações internacionais não-governamentais (ONGs)" E arremata: "Uma organização intergovernamental é um organismo que é estabelecido pelos governos participantes, ao qual é dada a responsabilidade de regular e supervisionar um domínio particular da atividade que é de alcance transnacional" GIDDENS, Anthony. Op. cit., p. 64.

${ }^{7}$ BAuman, Zygmunt. A sociedade individualizada: vidas contadas e histórias vividas. Rio de Janeiro: Jorge Zahar, 2008. p. 61.

${ }^{8}$ BAUMAN, Zygmunt. Ob. cit., p. 44.
} 
Desta forma, as pessoas se veem tomadas por Unsicherheit porque faz parte integrante de suas vidas a ausência de previsibilidade sobre seus destinos, sobre sua sorte na vida, havendo até mesmo o sentimento de falta de controle sobre seu caminho ${ }^{9}$.

Daí porque ZYGMUNT BAUMAN fala da globalização como "nova desordem mundial" ${ }^{\prime 10}$. Este sentimento de insegurança (Unsicherheit) que é característica da pósmodernidade, que a torna líquida, faz com que a flexibilização seja o "slogan do dia"11.

Há em BAUMAN um sentido negativo no uso de todos estes termos e dele nos afastamos. Sua visão de mundo leva a crer que a flexibilização e a nova ordem mostram-se como contrárias ao indivíduo e como mais uma forma de mecanismo de restrição de direitos.

O pensamento de ZYGMUNT BAUMAN tem importante função descritiva do mundo. A identificação desta nova ordem mundial e da própria flexibilização são importantes contribuições de seu trabalho, no entanto, não é possível extrair deste o caráter opressivo que o autor apresenta.

Vemos na pós-modernidade a desvalorização da ordem tal como conhecida e que é apresentada por ZYGMUNT BAUMAN como "A nova desordem mundial”, apelidada de "globalização", tem, no entanto, um efeito realmente revolucionário: a desvalorização da ordem:

"Uma eventualidade assim pode ser entrevista na análise de CROZIER, ou mesmo antecipada em vista da tendência notoriamente

\footnotetext{
${ }^{9}$ Mesmo nas Ciências ditas exatas, como é o caso da física, verifica-se a inquietação com o determinismo e a previsibilidade como apresenta ILYA PRIGOGINE ao afirmar: "arraigar o indeterminismo e a assimetria do tempo nas leis da física é a resposta que podemos dar hoje ao dilema de Epicuro. Senão, essas leis são incompletas, tão incompletas quanto se ignorasse a gravitação ou a eletricidade" (PRIGOGINE, Ilya. O fim das certezas: tempo, caos e as leis da natureza. São Paulo: Editora da Universidade Estadual Paulista, 1996. p. 23).

${ }^{10}$ BAuman, Zygmunt. A sociedade individualizada ... cit., p. 48.

${ }^{11}$ Embora a flexibilização seja vista por Bauman dentro da esfera da relação entre o capital e o trabalho, também se pode extrapolar seu sentido para os diversos aspectos da vida diária. É certo que o sociólogo vê sentido ruim no uso do termo flexibilização quando aplicado ao trabalho, afirmando que "como muitos valores de linha de frente, a idéia de 'flexibilidade' esconde sua natureza de relação social, o fato de que demanda a redistribuição de poder e implica uma intenção de expropriar o poder de resistência daqueles cuja 'rigidez'está a ponto de ser superada" (BAUMAN, Zygmunt. Globalização: as consequências humanas. Rio de Janeiro: Jorge Zahar Ed., 1999.p. 35. No entanto, como será visto no Capítulo 2, vemos outro sentido para o termo flexibilização.
} 
autodestrutiva de toda construção da ordem - mas só agora ela pode ser observada em todas as suas ramificações. No mundo que se globaliza, a ordem transforma-se em índice de falta de poder e de subordinação. A nova estrutura de poder global é operada pelas oposições entre mobilidade e sedentarismo, contingência e rotina, rarefação e densidade de imposições. É como se o longo trecho da história que começou com o triunfo dos sedentários sobre os nômades estivesse chegando ao final" 12 .

\subsection{Soberania}

A ideia de soberania também passa por mudanças profundas que conduzem à ideia de flexibilização. Desde a concepção inicial da soberania como poder absoluto percorreu-se longo caminho e, atualmente, sua concepção é diferente.

A noção original de soberania está expressa no brocardo suprema potestas superiorem non recognoscens (poder supremo que não reconhece outro acima de si) ${ }^{13}$.

Esta noção de soberania forma-se, em especial, com a paz de Westfalia, de 1648 que deu origem aos Estados soberanos. Com o surgimento destes Estados, teve-se então, a mudança em suas relações: de um lado, deveriam relacionar-se com seus súditos e, de outro, com outros Estados igualmente soberanos.

Na lição clássica, a soberania pode ser analisada em sua manifestação interna e em sua manifestação externa e, como bem demonstrou LUIGI FERRAJOLI, ambas as manifestações estão indissociavelmente ligadas ${ }^{14}$.

Segundo FerRajoli, é no plano da relação interna com seus súditos que é percebida a quebra no sentido clássico de soberania a partir da Revolução Francesa: o

\footnotetext{
${ }^{12}$ BAUMAN, Zygmunt. A sociedade individualizada ... cit., p. 48-49.

${ }^{13}$ Ferrajoli, Luigi. A soberania no mundo moderno: nascimento e crise do estado nacional. 2. ed. São Paulo: Martins Fontes, 2007. p. 1.

${ }^{14}$ FERRAJOLI, Luigi. Op. cit., em especial as observações contidas na p. 41.
} 
sentido absoluto e interno da soberania deixa de existir, ocorrendo progressiva limitação do poder estatal por meio das declarações dos direitos fundamentais ${ }^{15}$.

No entanto, quanto mais se limitava o poder soberano no âmbito interno, mais era proclamado o Estado como absoluto no âmbito externo. Neste sentido, cabe a lição de LUIGI FERRAJOLI:

"O estado de direito, internamente, e o estado absoluto, externamente, crescem juntos como os dois lados da mesma moeda. Quanto mais se limita - e, através de seus próprio limites, se autolegitima - a soberania interna, tanto mais se absolutiza e se legitima, em relação aos outros Estados e sobretudo em relação ao mundo "incivil", a soberania externa"16.

Esta soberania externa foi mantida praticamente intacta até o advento das Guerras Mundiais e, o seu final, com o surgimento da ONU e da Declaração Universal dos Direitos do Homem e os sucessivos pactos que surgiram. A partir do surgimento de regras que passaram a limitar também a atuação externa dos Estados, foi tido outro ataque ao conceito clássico de soberania, agora em sua vertente externa.

\section{Novamente LUIGI FERRAJOLI:}

"Sua crise - agora o podemos afirmar, começa justamente, tanto na sua dimensão interna quanto naquela externa, no mesmo momento em que a soberania entra em contato com o direito, dado que ela é a negação deste, assim como o direito é a sua negação. E isso uma vez que a soberania é a ausência de limites e de regras, ou seja, é o contrário daquilo em que o direito consiste. Por essa razão, a história jurídica da soberania é a história de uma antinomia entre

\footnotetext{
${ }^{15}$ Afirma FerRAJOLI: “(...) dá seu primeiro passo com o ocaso do absolutismo régio e com o nascimento do Estado liberal. Com a Declaração dos direitos do homem e do cidadão, de 1789, e depois com as sucessivas cartas constitucionais, muda a forma do Estado e, com ela muda, até se esvaziar, o próprio princípio da soberania interna." Op., cit., p. 28.

${ }^{16}$ Idem. p. 35.
} 
dois termos - direito e soberania -, logicamente incompatíveis e historicamente em luta entre si"17.

Em suma, o autor vê o nascimento e a morte do conceito de soberania (em sua dupla dimensão) de maneira concomitante ao próprio nascimento e ascensão do Estado de Direito.

Esta ideia de limitação da soberania por força do Direito mostra-se correta. No entanto, não se mostra correta a ideia de LUIGI FERRAJOLI de que não existe mais soberania no mundo atual. O que houve foi uma mudança de concepção.

\subsection{1 - Soberania e flexibilização: a mudança de paradigmas}

A crise no conceito de soberania conduz a uma mudança do seu próprio paradigma. O paradigma anterior amparado na desconfiança, base para a sustentação de um poder ilimitado dos Estados, não se motra mais como adequado e não corresponde à realidade mundial, sendo necessária sua superação. Deve-se superar o paradigma da desconfiança para que se caminhe em direção ao paradigma da confiança.

Quando os Estados colocavam-se de maneira absoluta em suas relações externas, apresentavam-se entre si como iguais e, por isso, conviviam em um mundo em que imperava a desconfiança. O diferente gerava em outro Estado, automaticamente, repúdio. Tome-se como exemplo o tema da Cooperação Jurídica Internacional, quando a cooperação era facilitada entre Estados com sistemas jurídicos similares.

Chegava-se mesmo a recusar a cooperação mediante e, principalmente, em virtude da "ordem pública" e, neste quadro, o cumprimento de decisões executórias emitidas por um país a outro era algo impensável.

No entanto, com a evolução das relações entre os Estados, a globalização teve a necessidade da mudança de paradigma. Estabeleceu-se um novo paradigma em que os Estados não atuariam mais com a desconfiança que era a base do modelo até então vigente.

\footnotetext{
${ }^{17}$ Idem, p. 44.
} 
Vem de PETER HÄBERLE a elaboração teórica deste novo modelo em oposição ao anterior. Em texto de 1977 referiu o surgimento daquilo que denominou de "Estado Constitucional Cooperativo". ${ }^{18}$

Para Peter HÄBerle este Estado Constitucional Cooperativo foi fundado e limitado juridicamente por meio de princípios constitucionais materiais e formais:

“É o Estado no qual o (crescente) poder social também é limitado através da 'política de Direitos Fundamentais' e da separação social (por exemplo, 'publicista') de Poderes" ${ }^{19}$.

Em suma, o Estado Constitucional Cooperativo está centrado no respeito aos direitos fundamentais ${ }^{20}$, que é base para o desenvolvimento das relações jurídicas entre os diversos Estados.

O novo paradigma da confiança conduz o Estado a ampliar seu alcance ${ }^{21}$. No paradigma da desconfiança, um nacional poderia muito bem, em uma série de situações,

${ }^{18}$ HÄBERLE, Peter. Estado Constitucional cooperativo. Rio de Janeiro: Renovar, 2007, p. 6.

${ }^{19}$ Idem, ibidem.

${ }^{20}$ Neste sentido é HÄBERLE quem faz o alerta sobre os limites e perigos deste estado ao afirmar: "o Estado constitucional ocidental é, quantitativamente, somente um tipo relativamente raro de Estado. De um lado, ele concorre com os chamados Estados 'socialistas' e, de outro, com Estados autoritários ou totalitários na Europa, África, América Latina e Ásia. Seria de pouca visão, até mesmo perigoso, se a dogmática constitucional não visse esse conjunto de fatos, se ela construísse - entusiasmada pelo seu próprio modelo formas européias de cooperação que abrissem os Estados de tal forma que estes ficassem expostos a perigos pelos Estados ‘selvagens' (que são, por sua vez, sujeitos de Direito Internacional)”. Op., cit., p. 20.

${ }^{21}$ Há, é claro, resistências a este modelo. Por todos, veja-se a crítica de José DE FARIA CosTA: “de forma sintética poder-se-á sustentar, sem quebra de rigor analítico, que a noção de Estado e as suas específicas funções de soberania entraram em crise não só por força de circunstâncias exógenas mas também por mor de condições endógenas. Ou seja: por força de pressões internas e externas que, todavia, parecem todas confluir no sentido da desarticulação e desagregação do Estado, tal como o temos concebido até aos nossos dias. Assim, externamente é cada vez mais puxado para espaços políticos supranacionais (veja-se o que se passa, por exemplo, na União Europeia). Espaços políticos supranacionais muitíssimo mais vastos onde as decisões que se reflectem nos diferentes Estados nacionais são tomadas por estruturas ou órgãos de decisão de escassa legitimidade democrática e que, para além disso, se encontram afastadíssimos da realidade específica e concreta de cada País. É bem verdade que para combater esta voragem centrípeta das estruturas ou órgãos supranacionais se defende o princípio da subsidiaridade. Mas não é também menos verdade saber-se da pouca eficácia de um tal princípio em uma época de indefinição ou de indecisão como a que se vive. Depois, internamente, o Estado sofre o desgaste de todos os movimentos de regionalização e autonomia - o constante aumento dos chamados poderes sub-estaduais - que se têm acentuado ultimamente. Sofre, para além de tudo sendo esta, talvez, a característica mais saliente de todo este processo -, a privatização de um conjunto de tarefas e funções que eram até então tidas como pilares sacrossantos do Estado. Pense-se, nomeadamente, na saúde, na educação, nas telecomunicações etc. E se a segurança interna e a defesa, chamemos-lhes nucleares, é ainda tarefa do Estado, já se vêem proliferar formas privadas de segurança e propugnar-se até, por exemplo, não a compra de material bélico mas antes a efectivação de contratos leasing sobre esse mesmo material 
conseguir "imunidade" por seus atos simplesmente cruzando a fronteira de seu país. Já no paradigma da confiança, os Estados prometem cooperar entre si de forma que este mesmo nacional já não mais está imune pelo simples atravessar de uma fronteira ${ }^{22}$.

Enfim o Estado Constitucional Cooperativo confia no sistema internacional e nos demais Estados ${ }^{23}$. O fato de seu fundamento repousar no respeito aos Direitos Humanos facilita este mútuo reconhecimento e torna mais seguras as bases de relacionamento entre os Estados que não mais possuem motivos para desconfiar de outros sistemas jurídicos.

Este modelo de Estado não é um fim em si mesmo, nem encontra-se pronto e acabado $^{24}$. O Estado Constitucional Cooperativo é um modelo a ser perseguido e que encontra vários desafios para sua implementação ${ }^{25}$.

bélico. O que tudo mostra, se necessário fosse, o acerto da posição analítica de todos os que sustentam e seguem o discorrer que se acabou de proceder." (COSTA, José de Faria. O fenómeno da globalização e o direito penal econômico. RBCCrim, n. 34, p., São Paulo, RT, abr. 2001.).

${ }^{22}$ Neste sentido afirma PETER HÄBERLE que: "o Estado Constitucional cooperativo vive de necessidades de cooperação no plano econômico, social e humanitário, assim como - falando antropologicamente - da consciência da cooperação (internacionalização da sociedade, da rede de dados, opinião pública mundial, das demonstrações com temas de política externa, legitimação externa).” Op. cit., p. 19.

${ }^{23}$ Bem por isso, afirma ANDRÉ DE CARVALHO RAMOS: "portanto, não é mais cabível, hoje, que um Estado alegue, na defesa de suas condutas violatórias de direitos humanos, que a proteção de direitos humanos faz parte de seu domínio reservado, e que eventual averiguação internacional (mesmo que mínima) da situação interna de direitos humanos ofenderia sua soberania”. RAMOS, André de Carvalho. Direitos humanos em juízo, comentários aos casos contenciosos e consultivos da Corte Interamericana de Direitos Humanos e estudo da implementação dessas decisões no direito brasileiro. São Paulo: Max Limonad, 2001. p. 77.

${ }^{24}$ Neste sentido, merece destaque a lição de GUIDO F. SOARES: "a evolução do Direito Internacional, por outro lado, revelou que os fenômenos oriundos dos relacionamentos internacionais exigiam algo mais do que uma simples abstenção por parte dos Estados e, sendo assim, em especial no correr do séc. XX, novo conteúdo foi-lhe acrescentado: o dever de cooperação, entendido não mais como um ideal a ser atingido, segundo o desiderato dos grandes filósofos moralistas dos séculos anteriores, mas como uma necessidade de os Estados poderem atingir a determinados objetivos. A dimensão de um dever de cooperação, como condição para a efetividade das ações dos Estados nos relacionamentos com outros, se tornou, portanto, uma característica fundamental do Direito Internacional, como comprovam as próprias experiências de integração econômica regionais, motivadas antes por necessidades pragmáticas do que por um ideal de cooperação, com vistas a um conteúdo mais equitativo nos relacionamentos interestatais”. SoARES, Guido F. S. União Europeia, Mercosul e a proteção dos direitos humanos. In: PIOvesAn, Flávia (coord.). Direitos Humanos, globalização econômica e integração regional: desafios do direito constitucional internacional. São Paulo: Max Limonad, 2002. p. 123).

${ }^{25}$ Rejeita-se, portanto, neste aspecto a crítica apresentada por JEREMY WALDROM que vê dicotomia na aplicação das decisões internacionais como se fosse mera questão atinente a opção entre a lei como vontade e a lei como razão: "I am under no illusion, however, that the practice of the Supreme Court in Roper and in other cases actually answers to the characterization I have given. Practice often falls short of theory particularly when the practitioners have not shown much awareness of the theory in question! And there are all sorts of pitfalls and temptations associated with a theory as loose as this. No crisp or precise litmus test defines the sort of international consensus that makes up ius gentium on any particular subject. It is, as we have seen, a matter of interpretation, and so there is always the prospect that a judge will invoke this theory opportunistically, picking and choosing the consensus he relies on, to reinforce conclusions that he wanted to reach anyway. For those who see law as a matter of will, this sort of theory is at best just an opportunity for 


\title{
1.3 - Tecnologia e flexibilização
}

\author{
Nossa época é marcada pela velocidade do avanço das mudanças tecnológicas. \\ O atual período da história é caracterizado pelo aumento da velocidade das mudanças \\ tecnológicas sem que haja precedentes na história do homem.
}

NICOLAU SEVCENKO esclarece:

\begin{abstract}
"Essa situação transparece com clareza na taxa de crescimento dos conhecimentos técnicos, que desde o começo do século XX é de treze por cento ao ano. $\mathrm{O}$ que significa que ela dobra a cada cinco anos e meio. Alguns teóricos calculam que, em vista das novas
\end{abstract}

haphazard legitimation. But for those who do see legal decision as a matter of reasoning one's way through problems, my account may help to explain why courts turn naturally to foreign law. The real contrast between those who oppose and those who defend the use of foreign law in American legal reasoning is not that jurists in the first group are parochial and the second cosmopolitan. It is rather this contrast between law as will and law as reason. Those who approach the law as a matter of will do not see any reason why expressions of will elsewhere in the world should affect our expressions of will in America. But those who see law as a matter of reason may well be willing to approach it in a scientific spirit that relies not just on our own reasoning but on some rational relation between what we are wrestling with and what others have figured out." WALDROM, Jeremy. Foreign law and the modern ius gentium. Harvard Law Review, v. 119, p. 146-147. Realmente temos um problema quando o julgador simplesmente decide optar entre um sistema e outro como apontado na crítica, no entanto o problema não está na vontade contra a razão como opções antitéticas. O problema maior está na falta de critérios científicos e por isso a crítica do pick and choose feita é válida. No entanto, este pick and choose existe em cada uma das escolhas feitas pelo julgador sobre qual sistema interno usar. A questão, então, está em fazer com que o julgador passe a utilizar critérios lógicos na escolha e não meramente critérios arbitrários: "Eu estou sob nenhuma ilusão, no entanto, convencido que a prática do Supremo Tribunal Federal em Roper e em outros casos, na verdade, responde à caracterização que tenho dado. A prática muitas vezes fica aquém da teoria - principalmente quando os praticantes não têm demonstrado muita consciência da teoria em questão! E há todos os tipos de armadilhas e tentações associadas com uma teoria tão solta como esta. Nenhum teste decisivo, nítido ou preciso define o tipo de consenso internacional de que faz-se ius gentium sobre qualquer assunto particular. É, como vimos, uma questão de interpretação, e por isso há sempre a perspectiva de que um juiz irá chamar esta teoria oportunista, escolhendo o consenso que ele se baseia, para reforçar as conclusões que ele queria chegar de qualquer maneira. Para aqueles que vêem a lei como uma questão de vontade, este tipo de teoria é a melhor em apenas uma oportunidade para a legitimação casual. Mas para aqueles que vêem a decisão jurídica como uma questão de forma um raciocínio por meio de problemas, minha conta pode ajudar a explicar por que os tribunais se viram naturalmente para a lei estrangeira. $\mathrm{O}$ contraste real entre aqueles que se opõem e aqueles que defendem o uso do direito estrangeiro no raciocínio jurídico norte-americano não é que juristas do primeiro grupo são paroquial e cosmopolita do segundo. É um pouco esse contraste entre a lei como vontade e lei como razão. Aqueles que se aproximam da lei como uma questão de vontade não veem nenhuma razão para que expressões da vontade de outras partes do mundo deva afetar nossas expressões de vontade nos Estados Unidos. Mas aqueles que vêem a lei como uma questão de razão podem muito bem estar dispostos a abordá-la em um espírito científico que se baseia não apenas no nosso próprio raciocínio, mas em uma relação racional entre o que estamos lutando com o que os outros e ter descoberto ". 
possibilidades introduzidas pela Revolução Microeletrônica, em inícios do século XXI, essa taxa tenderá a ser da ordem de mais de quarenta por cento ao ano, chegando praticamente a dobrar a cada período de doze meses" 26 .

Um dos marcos desta revolução tecnológica é a internet. A internet e a cultura do virtual mudaram a nossa forma de relacionamento com as outras pessoas e com a realidade que nos cerca.

Fala-se, atualmente, em cibercultura como sendo a

"formação histórica de cunho prático e cotidiano, cujas linhas de força e rápida expansão baseadas nas redes telemáticas, estão criando, em pouco tempo, não apenas um mundo próprio mas, também, um campo de reflexão intelectual pujante, dividido em várias tendências de interpretação"27.

Um dos grandes teóricos da internet, o sociólogo MANuEl CASTELls, nos ensina que a internet não é apenas uma tecnologia. Na verdade, a internet representa um meio de comunicação e a própria infraestrutura da organização da rede ${ }^{28}$.

A internet afetou de maneira profunda a própria noção de soberania, na medida em que os Estados foram obrigados a repensar sobre o efetivo controle que detêm sobre a informação existente na internet e sobre os espaços a serem ocupados.

A geografia, agora, adquire, nova versão, na medida em que a atuação do indivíduo não é mais limitada ao espaço físico do Estado, atua o indivíduo com a geografia do próprio globo. Seu limite é o espaço mundial ${ }^{29}$.

\footnotetext{
${ }^{26}$ SEvCEnKo, Nicolau. A corrida para o século XXI: no loop da montanha russa. São Paulo: Companhia das Letras, 2009. p. 24.

${ }^{27}$ RÜDIGER, Francisco. As teorias da cibercultura, perspectivas, questões e autores. Porto Alegre: Sulina, 2011, p. 7.

${ }^{28}$ CASTELLS, Manuel. A galáxia da internet: reflexões sobre a internet, os negócios e a sociedade. Rio de Janeiro: Zahar, 2003. p. 116: "Sabemos, a partir dos capítulos precedentes, que a internet não é simplesmente uma tecnologia: é um meio de comunicação (como eram os pubs), e é a infra-estrutura mateerial de uma determinada forma organizacional: a rede (como era a fábrica)".

${ }^{29}$ Novamente CASTELLS nos ensina: "a Era da internet foi aclamada como o fim da geografia. De fato, a internet tem uma geografia própria, uma geografia feita de redes e nós que processam fluxos de informação gerados e administrados a partir de lugares. Como a unidade é a rede, a arquitetura e a dinâmica de múltiplas
} 
Assim, é possível que um cidadão no Brasil arquive documentos em determinado serviço oferecido por site situado em país a quilômetros de distância do Brasil. A configuração geográfica da internet adquire contornos próprios e distintos do plano físico a que estamos acostumados a pensar.

As limitações ao controle do Estado sobre a internet (e a própria inviabilidade deste controle) acabam por solapar a autoridade e o poder do Estado neste campo. As tentativas de controle da internet pelo Estado acabam por produzir resultados ainda tímidos ${ }^{30}$.

A intimidade ficou enfraquecida com a internet. O monitoramento na internet é algo real e efetivo ${ }^{31}$. A influência da internet é tão grande que a vida hoje é, em grande parte, virtual. Por isso influi no Direito e também no direito processual penal. Questões atinentes à competência e, em especial, aos meios de obtenção de prova adquiriram novos contornos.

A flexibilização manifesta-se na tecnologia por conta da velocidade das mudanças e pelas novas formas de interação entre as pessoas. As mudanças são tão rápidas e tão profundas que alteram diariamente a forma da relação dos indivíduos com o mundo e com as outras pessoas.

Assim, por exemplo, basta pensar nas mudanças existentes nos últimos dez anos. Caso seja comparado o mundo há dez anos com o mundo atual percebe-se como

redes são as fontes de significado e função para cada lugar. O espaço de fluxos resultante é uma nova forma de espaço, característico da Era da Informação, mas não é desprovida de lugar: conecta lugares por redes de computadores telecomunicadas e sistemas de transporte computadorizados. Redefine distâncias mas não cancela a geografia. Novas configurações territoriais emergem de processos simultâneos de concentração, descentralização e conexão espaciais, incessantemente elaborados pela geometria variável dos fluxos de informação global” (CASTELlS, Manuel. Op. cit., p. 70).

${ }^{30}$ Novamente recorre-se a CASTELLS que ensina que “(...) a internet solapou decisivamente a soberania nacional e o controle do Estado. Mas só o pôde fazer por causa da proteção judicial que recebeu no núcleo de seu backbone global, os EUA." CASTELLS, Manuel. Op. cit., p. 140.

No entanto, não deixa de ser curioso que o próprio Estado precisou recorrer aos conceitos de Estado Constitucional Cooperativo na tentativa de retomada do espaço da internet: "A primeira vítima dessa retomada de posse do ciberespaço é a própria soberania. Para exercer a regulação global, os Estados tem de fundir e compartilhar poder. Não segundo o sonho ultrapassado de um governo mundial, mas como um Estado em rede, a criatura política engendrada pela Era da Informação.” CASTELLS, Manuel. Op. cit., p. 147).

${ }^{31}$ Não se trata, como diz CASTELlS, de “(...) medo do Big Brother porque, na verdade, a maior parte da vigilância não terá nenhuma consequência diretamente danosa para nós - ou ,aliás, nenhuma consequência em absoluto. $\mathrm{O}$ aspecto mais atemorizante é, de fato, a ausência de regras explícitas de comportamento, de previsibilidade das consequências de nosso comportamento exposto, segundo os contextos de interpretação, e de acordo com os critérios usados para julgar nosso comportamento por uma variedade de atores atrás da tela de nossa casa de vidro. Não é o Big Brother, mas uma multidão de irmãzinhas, agências de vigilância e processamento de informação que registram nosso comportamento para sempre, enquanto bancos de dados nos rodeiam ao longo de nossa vida (...)."CASTELLS, Manuel. Op. cit., p. 149. 
novas formas de relação foram criadas por conta dos novos produtos tecnológicos desenvolvidos.

A legislação, contudo, não avançou na mesma velocidade. Daí porque há necessidade de flexibilização na aplicação do Direito para que se possa atender satisfatoriamente as necessidades do indivíduo ${ }^{32}$.

\section{4 - O processo no mundo pautado pela flexibilização}

O Direito deve refletir o mundo que o cerca, a sociedade em que vivemos como salienta TERESA ARMENTA DEU ${ }^{33}$. Um processo alheio à sociedade e seus valores é um processo que carece de legitimidade. CALAMANDREI escreveu, em 1939, sobre a relação entre a sociedade e o processo: o processo é a manifestação dos valores da

\footnotetext{
${ }^{32}$ Pierre Levy ensina a este respeito "Em primeiro lugar, que o crescimento do ciberespaço resulta de um movimento internacional de jovens ávidos para experimentar, coletivamente, formas de comunicação diferentes daquelas que as mídicas clássicas nos propõem. Em segundo luga, que estamos vivendo a abertura de um novo espaço de comunicação, e cabe apenas a nós explorar as potencialidades mais positivas deste espaço nos planos econômico, político, cultural e humano", LEVY, Pierre. Cibercultura. São Paulo: Ed. 34, 1999, p.11.

${ }^{33}$ TERESA ARMENTA DEU afirma: "así como el fin de todo processo penal es la búsqueda de la verdade y la verificación de la justicia imponiendo em sua caso uma pena, la forma que este processo adquiera varía según la concepción que se tenga del Derecho Penal substantivo y de los factores políticos y sociales dominantes em cada época. En efecto, aunque en origem la justifica penal adoptó uma forma que correspondia a uma concepción privada del Derecho Penal y por ende el primer sistema procesal penal fue el acusatório em su sentido estricto, el Derecho Penal em su configuración acutal viene determinado por la necessidade de un processo como única forma de imponer uma pena, lo que a su vez implica que no exista um arelación jurídica material penal, ni um derecho subjetivo a la citada imposición por quienes ejercitan la acción penal. De la misma naturaleza se infiere que al renunciarse al ejercicio de la acción penal por los particulares, atribuyendo tal función a um órgano oficial como el fiscal, se halla acompañado tradicionalmente dicha atribución de la garantia ínsita em el sometimiento de tal función al principio de legalidade. Otras opciones hacen prevalecer otros valores." DEU, Teresa Armenta. Estudios sobre el processo penal. Santa Fé/Argentina: Rubinzal-Culzoni, 2008. p. 82). Em tradução livre: "Assim como o fim de todo processo penal é a busca da verdade e a verificação da justiça impondo a cada caso uma pena, a forma que este processo adquire varia segundo a concepção que se tenha do Direito Penal substantivo e dos fatores políticos e sociais dominantes em cada época. De fato, ainda que na origem a justiça penal tenha adotado uma forma que correspondia a uma concepção privada do Direito Penal e, por consequência, o primeiro sistema processual penal foi o acusatório em seu sentido estrito, o Direito Penal em sua configuração atual vem determinado pela necessidade de um processo como única forma de impor uma pena, o que a sua vez implica que não exista uma relação jurídica material penal, nem um direito subjetivo à citada imposição por aqueles que exercem a ação penal. Da mesma forma se infere que ao se renunciar ao exercício da ação penal pelos particulares, atribuindo tal função a um órgão oficial como o Ministério Público, faça-se acompanhar tradicionalmente dita atribuição da garantia ínsita na submissão de tal função ao princípio da legalidade. Outras opções fazem prevalecer outros valores".
} 
sociedade $^{34}$. Daí porque a flexibilização que ocorre no mundo, como visto acima, em virtude da globalização se manifesta no Direito e no processo. A flexibilização gerada no processo penal deve ser vista, contudo, com cuidado para que não se abandonem as garantias criando um sistema sem qualquer proteção ao indivíduo ${ }^{35}$.

${ }^{34}$ Piero CALAMANDREI já ensinava, em 1939, a relação entre o processo e a sociedade. Em seu texto " $L a$ relatività del concetto di azione" explica: "si deve vedere nel processo civile un servizio que lo Stato rende al citadino, fornedogli il mezzo per atuarei l suo diritto soggetiv, o vero um servizio que il citadino rende a lo Stato, fornendogli l'ocazione per atuare il diritto oggetivo? In torno a questo problema essencial ela polemica ha rimessoin discussione tutti i concetti primi dela mostra scienza, giurisdizione, azione, rapporto processuale, loro natura giuridica e loro scopi; ma in realtà ala base di ogni discussione su questi molteplici aspetti dela polemica il vero problema di cui si discuteva, era, sai pur tradotto in termini di recnica processuale, uno solo: quello, che riaffiora oggi in tutti i campi del pensiero, dela relacioni tra interesse individuale e interesse pubblico, tra citadino e Stato, tra libertà e autorità. La polemica ha dunque uno sfondo essenzialmente politico; $m$ aquesto avviene, ed è bene che avvenga, anche se non sempre i giuristi se ne accorgono, in ogni elaborazione sistemática degli istituti giuridice nel interpretare i quali i tecnici, anche quando credono di essere fedegli alla lereta degli disposizione positive, non possono eximersi dall'esaminarli contro luce al chiarore di certe fondamentali tendenze, alle quali essi pensano che si inspiri, o vorrebbero che si inspirasse, l'ordinamento entro il quale quel diritto positivo è collocato. Le ricostruzioni della dogmática sono dunque, in ogni caso, il risultato di um compromisso trai l diritto positivo e le premesse tendenziali a cui il giurista lo ricollega: ed è cosi, coll'evolversi di queste mobili premesse, che la dogmática riesce a ringiovanireperennemente gli istituti giuridici, e ad adeguarli, anche se la lettera dele disposiizoni rimane immutata, alla realtà sociale che sempre si rinnova. Esempio orami clássico di questa funzione di adeguazione politica che la dogmativa exercita sul diritto positivo, è data próprio, come altrove ho notato, dall'opera scientifica di Giuseppe Chiovenda (...)." CALAMANDREI, Piero. La relatività del concetto di azione. Rivista di Diritto Processuale Civile, v. XVI, parte 1, p. 22, 1939. Em tradução livre: "deve-se ver no processo civil um serviço que o Estado presta ao cidadão, fornecendo os meios para fazer valer direito seu, ou um serviço que o cidadão faz ao Estado, fornecendo-lhe casos para aplicação do direito objetivo? Baseado em torno deste problema deve-se analisar os conceitos de ciência, jurisdição, ação, relação processual, sua natureza jurídica e sua finalidade; mas na realidade a vase de qualquer discussão sobre os múltiplos aspectos da polêmica o verdadeiro problema de que se discutia era: a de que ressurge hoje em todos os campos do pensamento, a relação entre o cidadão e o Estado, entre liberdade e autoridade. A polêmica tem, portanto, um fundo essencialmente político. E é bom que isso aconteça, mas nem sempre os juristas realizam esta análise na elaboração sistemática dos institutos jurídicos e no interpretá-los. Ainda que creiam ser fieis à literalidade das disposições positivadas, não podem eximir-se de analisá-las à luz de certas tendências fundamentais, que eles pensam inspirar, ou gostariam que se inspirasse, o ordenamento no qual o direito positivo é colocado. As reconstruções dogmáticas são, portanto, em qualquer caso, o resultado da ligação entre o direito positivo e as premissas ideloógicas às quais o jurista se filia: e é assim, com o desenvolver-se destas premissas móveis que a se consegue rejuvenescer as instituições jurídicas e adequá-las à realidade sócia que sempre se renova, ainda que a letra da lei permaneça imutável."

${ }^{35}$ LUIZ ARROYo ZAPATERO nos mostra, contudo, como essa verificação é frágil e como as tensões ainda permeiam o processo penal especialmente no pós 11 de Setembro: "também pertence ao que foi consolidado neste tempo a ideia de que a justiça penal tem de se realizar através do denominado 'devido processo' ( due process). Penso que esta é a grande contribuição dos Estados Unidos da América ao progresso dos direitos humanos em sua elaboração teórica: o devido processo e uma mutação na ideia de política criminal, o que, em termos germânicos, poderia se resumir na afirmação de que se a política criminal moderna se originou nos textos de von Liszt, amadureceu na concepção de Direito Penal e de política criminal de Roxin, mas que também poderia ser formulada, ao que a mim concerne, nos postulados da moderna Defesa Social, especialmente após a Addenda de 1983. Às vezes se pensa que alguns países alcançaram certa orgia garantista, especialmente quando se vê como e em que condições os tribunais, aplicando a doutrina constitucional das provas proibidas, optam pela liberdade mesmo em casos de culpabilidade manifesta. Tem razão Zaffaroni ao dizer que, em realidade, o Estado, por melhor que pareça, sempre é Estado e tende ao excesso, e que todo o esforço para "encapsular" esse poder do Estado é justo e necessário. Para mim, em seu momento, esta ideia me pareceu excessiva, mas deixou de sê-la quando o instrumento de política criminal mais respeitado do mundo, denominado Scotland Yard, disparou para matar um jovem brasileiro que somente queria pegar seu metrô a tempo. O fato é que desde o ponto de vista dos direitos humanos não 
Uma das principais conquistas do direito processual foi a segurança jurídica ofertada pelo modelo desenvolvido. Para isso importava, muito, por exemplo, a força da própria rigidez do procedimento. Sabidas de antemão as regras procedimentais, sabidos são os caminhos e os rumos do processo, o que gera segurança para as partes.

\section{No entanto, esta característica importante do processo de modelo rígido} acabava por assemelhar o modelo processual no mesmo modelo de produção industrial fordista, como se o processo fosse uma linha de produção em que os sujeitos devessem a ele adaptar-se, pouco importando as peculiaridades do caso concreto.

Este modelo rígido contrasta nitidamente com o mundo marcado pela fluidez e a Unsicherheit ${ }^{36}$.

podemos fiar-nos nem mesmo da Scotland Yard. Depois do 11 de setembro se produziu um retrocesso impressionante relacionado aos direitos dos cidadãos, especialmente no que concerne à perseguição penal e policial: sequestros em traslados ilegais para Guantánamo e outros lugares por conhecer, execuções extrajudiciais, entregas ou extradições ilegais, vulneração do Direito Internacional Humanitário, consagração da tortura como método de verificação da verdade e como prova penal etc. Mesmo sem esperar que ocorressem mudanças nos Estados Unidos, os Tribunais de distintos países reagiram e se viram obrigados a declarar novamente que as declarações obtidas sob tortura em outro país não podem ser admitidas como prova em um processo penal. A Câmara dos Lordes declarou proibido o uso em juízo de provas obtidas em outro país mediante tortura, com ou sem rapto prévio e traslado do sequestrado de um país a outro. O assunto é bastante conhecido. Em consequência, não nos encontramos ante um excesso de garantismo. Na verdade, perto de tudo que está ocorrendo, todo o garantismo é pouco. Sem prejuízo dos excessos mencionados da "guerra contra o terror", o certo é que o mais forte movimento harmonizador está se formando na esfera mais sensível para os direitos do acusado no processo, dando um enorme passo na substituição dos restos do processo inquisitivo pelo acusatório. Na verdade, tanto na Europa quanto na América Latina, o juiz de instrução, tão querido por Napoleão, está a ponto da plena aposentadoria. O que se pode afirmar com certeza é que nos encontramos ante um incremento da criminalidade e ante uma representação social desta bem distinta." ZAPATERO, Luis Arroyo. A harmonização internacional do direito penal: ideias e processos. RBCCrim, n. 84, p. 49, São Paulo, RT, mai. 2010.

${ }^{36}$ Parece, inclusive, que no cotidiano já vemos esta prática da flexibilização, como bem notou GuSTAVo ZAGREBELSKY: "En la realidad de la administración de la justici, incluso donde está estabelecido que el juez sólo está sometido a la ley, la reconducción intehrgal de la justicia a la ley es desmentida por la más irrefutable de las pruebas, la prueba de los hechos. No se trata de uma recuperación de las teorías del derecho natual. Está fuera de discusión que la ley deriva de la determinación autônoma de los hombres, pero esto no excluyeuna distinción de los dos términos y de su recíproca tensión. La cotidiana y viva interpretación de la ley la acerca a las siempre cambiantes exigências reguladoras de la sociedade. Y esta interpretación evolutiva, que ningún legislador, desde Justiniano en adelante há sido capaz de impedi, qué es la manifestación de esa imprescindible conexión entre lo que está estabelecido y la razón por la que está estabelecido, es decir, su presupuesto? Si no fuera así, la interpretación evolutiva sería pura arbitrariedade." ZAGREBELSKY, Gustavo; MARTINI, Carlo Maria. La exigencia de justicia. Madrid: Miguel Carbonell, 2006. p. 33). Em tradução livre: "Na realidade da administração da justiça, inclusive onde está estabelecido que o juiz somente está submetido à lei, a recondução integral da justiça à lei é desmentida pela mais irrefutável das provas, a prova dos fatos. Não se trata de uma recuperação das teorias do direito natural. Está fora de discussão que a lei deriva da determinação autônoma dos homens, mas isso não exclui uma distinção dos dois termos e de sua recíproca tensão. A cotidiana e viva interpretação da lei a aproxima das sempre cambiantes exigências reguladoras da sociedade. E esta interpretação evolutiva, que nenhum legislador, desde Justiniano adiante foi capaz de impedir, que é a manifestação dessa imprescindível conexão entre o que está estabelecido e a razão por que está estabelecido, é dizer, seu pressuposto? Se não fosse assim, a interpretação evolutiva seria pura arbitrariedade." 
Isso tudo leva à necessidade de um estudo específico sobre a flexibilização e o processo penal. Pretende-se com este trabalho buscar o estabelecimento de parâmetros para que ocorra esta flexibilização e, posteriormente, pretende-se testar estes parâmetros com aspectos ligados diretamente ao processo penal: a) as medidas cautelares pessoais; b) a prova e o procedimento e c) a Cooperação Jurídica Internacional.

O que se pretende demonstrar é que a flexibilização não é contrária ao Direito, sendo, na verdade, uma necessidade ante as características do mundo atual. No entanto, também se busca comprovar que esta flexibilização necessita de parâmetros sob pena de violação das grandes conquistas da humanidade, notadamente em sede de direitos fundamentais.

Pretende-se deixar claro que a flexibilização não é a modificação do previsto pelo legislador sem qualquer parâmetro. Busca-se demonstrar que a flexibilização não é a modificação da lei de maneira desenfreada, mas submetida a parâmetros de legalidade, proporcionalidade e razoabilidade.

É certo que o processo com modelo mais flexível responderia aos anseios de liquidez da pós-modernidade, como também é verdade que este modelo precisa necessariamente levar em conta dois outros grandes elementos deste cenário, os direitos humanos e as Cortes Internacionais que vocalizam sua manifestação.

Ao mesmo tempo que requer-se fluidez, a pós-modernidade vê a última utopia como ainda extremamente influente: a temática dos direitos fundamentais. Quando pensase nos direitos fundamentais de resistência, então vê-se que a fluidez no processo deve ter limites, limites estes que não podem ferir de morte os direitos de resistência ${ }^{37}$, especialmente em nome de novas tecnologias.

\footnotetext{
${ }^{37}$ Também afirma GUSTAVO ZAGREBELSKY ao analisar a convivência dos princípios: "creo, por tanto, que la condición espiritual del tempo em que vivimos podría describirse como la aspiración no a uno, sino a los muchos princípios o valores que conforman la convivencia colectiva: a la libertad de la sociedade, pero también las reformas sociales; la igualdad ante la ley, y por tanto la generalidade de trato jurídico, pero también la igualdad respecto a las situaciones, y por tanto la especialidad de las reglas jurídicas; el reconocimiento de los derechos de los indivíduos, pero también de los derechos de la sociedade; la valoración de las capacidades materiales y espirituales de los indivíduos, pero también la protección de los bienes colectivos frente a la fuerzadestructora de aquéllos; el rigor em la aplicación de la ley, pero también la piedad ante sus consecuencias más rígidas; la responsabilidade individual em la determinación de la própria existência, pero también la intervención colectiva para el apoyo a los más débiles, etc". ZAGREBELSKY, Gustavo. El derecho dúctil. Ley, derechos, justicia. 7. ed. Madrid: Editorial Trotta, 2007. p.
} 
Da mesma forma, temos a atuação das Cortes Internacionais de Direitos Humanos. Ora, como admitir a flexibilização do que quer que seja, sem que sejam considerados os parâmetros ditados pelas Cortes Internacionais que são, hodiernamente, uma das vozes que declaram os direitos fundamentais?

Vale dizer, se de um lado temos a força da fluidez ${ }^{38}$ que empurra o processo em uma direção, de outro temos os Direitos Humanos e os Tribunais Internacionais que empurram o processo para outra ${ }^{39}$.

Daí porque, de tudo quanto o exposto, as críticas de GUSTAVo ZEGREBELSKY aos conceitos de Direito e sua própria definição são pertinentes:

"Conseguientemente, hoy em día el derecho no es sólo 'el conjunto de condiciones bajo las cuales el arbítrio de uno puede conciliarse com el arbitrio del otro según una ley universal de la libertad', como afirma la famosa definición kantiana. No es el puro y simple

16). ). Em tradução livre: Acredito, portanto, que a condição espiritual de que vivemos no tempo poderia ser descrita como o desejo de não um, mas para muitos princípios ou valores que compõem a vida coletiva: a liberdade da sociedade, mas também reformas sociais, a igualdade perante a lei e, portanto, a igualdade na generalidade de tratamento jurídico, mas também sobre as situações e, portanto, a especialidade das normas legais; o reconhecimento dos direitos dos indivíduos, mas também os direitos da sociedade; avaliação de capacidades materiais e espirituais dos indivíduos, mas também a protecção de bens coletivos contra a força destruidora desses; o rigor na aplicação da lei, mas também a sua piedade ante conseqüências mais rígidas, a responsabilidade do indivíduo na determinação da própria existência, mas também a intervenção coletiva para apoiar os mais fracos, etc".

${ }^{38}$ Assim Alfonso DE JULio CAMPUZANO afirma: "desse modo, a perda da função primordial da lei como fonte primária de produção normativa, sua 'descentralização' como critério diretamente de validade formal e material das diversas 'peças' que integram o ordenamento jurídico, provocou a consagração do valor primordial da Constituição, cujo caráter de norma suprema é agora elevado como elemento articulador da totalidade do ordenamento jurídico. O Estado constitucional de Direito abre, assim, uma nova etapa na evolução do próprio Estado de Direito, do modelo de organização jurídica que lhe é inerente e das elaborações teóricas da própria Ciência do Direito." CAMPUZANO, Alfonso de Julios. Constitucionalismo em tempos de globalização. Porto Alegre: Livraria do Advogado Editora, 2009.

${ }^{39}$ ANABELA MIRANDA RODRIGUES também entende esta necessidade de desburocratização do processo penal ensinando: "tempo e justiça tornam-se aliados. A exigir soluções imaginativas. Flexíveis e céleres, desde logo; mas, do mesmo passo, rigorosas no respeito pelos direitos fundamentais, quando a matriz da ordenação jurídico-processual é a intocabilidade da dignidade humana.Simplificação e imparcialidade do juiz são dois lugares - comuns das tendências de reforma dos processos penais na Europa. Simplificação e protecção dos direitos fundamentais, de um lado, não são necessariamente opostos. A imparcialidade do juiz, com a consequente revalorização da sua função jurisdicional ao longo de todo o processo (e não apenas na fase de julgamento), é, de outro lado, condição indispensável da garantia dos direitos fundamentais. Experiências relativamente recentes alertam para que uma justiça penal demasiado ritualizada, burocratizada e formalizada pode significar um pesado tributo a pagar pela proteç̧ão dos direitos fundamentais, traduzindo-se, paradoxalmente, na sua desprotecção." (RODRIGUES, Anabela Miranda. A fase preparatória do processo penal - tendências na Europa. O caso português. RBCCrim, n. 39, p. 09, São Paulo, RT, jul. 2002. 
formal 'acuerdo de los arbitrarios', según la despreciativa formula hegeliana. Es el conjunto de condiciones en las que necessariamente deben moverse las actividades publicas $y$ privadas para la salvaguardia de interesses materiales no disponibles. Es un orden objetivo previsto para limitar la inestabilidad de las vontades ",40.

\section{A flexibilização não é, em si mesma, algo necessariamente violador dos} direitos e garantias fundamentais ${ }^{41}$, como se verá no Capítulo 3. É preciso, primeiramente,

\footnotetext{
${ }^{40}$ ZAGREBELSKY, Gustavo. El derecho dúctil. Ley, derechos, justicia. 7. ed. Madrid: Editorial Trotta, 2007. p. 94. Em tradução livre: "Por conseguinte, hoje em dia o direito não é somente 'o conjunto de condições sob as quais o arbítrio de um pode se conciliar com o arbítrio do outro segundo uma lei universal e a liberdade', como afirma a famosa definição kantiana. Não é o puro e simples formal 'acordo dos arbítrios', segundo a depreciativa fórmula hegeliana. É o conjunto de condições em que necessariamente devem se mover as atividades públicas e privadas para a salvaguarda de interesses materiais indisponíveis. É uma ordem objetiva prevista para limitar a instabilidade das vontades"
}

${ }^{41}$ Nesta gama de temas tem-se que a proibição do retrocesso e a garantia da segurança são temas que não podem ser analisados de maneira antiética ou mesmo isolada. Estes princípios devem ser analisados conjuntamente e se entrelaçam com as premissas apresentadas anteriormente. Como bem analisado por Ingo Wolfgang Sarlet: "Sem que se pretenda aqui esgotar nem aprofundar isoladamente todo o leque de razões passíveis de serem referidas, verifica-se que, no âmbito do direito constitucional brasileiro, o princípio da proibição de retrocesso, como já sinalizado, decorre implicitamente do sistema constitucional, designadamente dos seguintes princípios e argumentos de matriz jurídico-constitucional: a) O princípio do Estado democrático e social de Direito, que impõe um patamar mínimo de segurança jurídica, o qual necessariamente abrange a proteção da confiança e a manutenção de um nível mínimo de segurança contra medidas retroativas e, pelo menos em certa medida, atos de cunho retrocessivo de um modo geral; b) $\mathrm{O}$ princípio da dignidade da pessoa humana que, exigindo a satisfação - por meio de prestações positivas (e, portanto, de direitos fundamentais sociais) - de uma existência condigna para todos, tem como efeito, na sua perspectiva negativa, a inviabilidade de medidas que fiquem aquém deste patamar; c) No princípio da máxima eficácia e efetividade das normas definidoras de direitos fundamentais contido no art. $5 .^{\circ}, \S 1 .^{\circ}$, CF/88 (LGL 198813), e que abrange também a maximização da proteção dos direitos fundamentais. Com efeito, a indispensável otimização da eficácia e efetividade do direito à segurança jurídica (e, portanto, sempre também do princípio da segurança jurídica) reclama que se dê ao mesmo a maior proteção possível, o que, por seu turno, exige uma proteção também contra medidas de caráter retrocessivo, inclusive na acepção aqui desenvolvida; d) As manifestações específicas e expressamente previstas na Constituição, no que diz com a proteção contra medidas de cunho retroativo (na qual se enquadra a proteção dos direitos adquiridos, da coisa julgada e do ato jurídico perfeito) não dão conta do universo de situações que integram a noção mais ampla de segurança jurídica, que, de resto, encontra fundamento direto no art. 5. ${ }^{\circ}$, caput, da CF/1988 (LGL 198813 ) e no princípio do Estado social e democrático de Direito; e) O princípio da proteção da confiança, na condição de elemento nuclear do Estado de Direito (além da sua íntima conexão com a própria segurança jurídica) impõe ao poder público - inclusive (mas não exclusivamente) como exigência da boa-fé nas relações com os particulares - o respeito pela confiança depositada pelos indivíduos em relação a uma certa estabilidade e continuidade da ordem jurídica como um todo e das relações jurídicas especificamente consideradas; f) Os órgãos estatais, especialmente como corolário da segurança jurídica e proteção da confiança, encontram-se vinculados não apenas às imposições constitucionais no âmbito da sua concretização no plano infraconstitucional, mas estão sujeitos a uma certa auto-vinculação em relação aos atos anteriores. Esta, por sua vez, alcança tanto o legislador, quando os atos da administração e, em certa medida, dos órgãos jurisdicionais, aspecto que, todavia, carece de maior desenvolvimento do que o permitido pelos limites do presente estudo; g) Negar reconhecimento ao princípio da proibição de retrocesso significaria, em última análise, admitir que os órgãos legislativos (assim como o poder público de modo geral), a despeito de 
que se defina do que é tratado quando se fala em flexibilização. Saber o que pode ser objeto da flexibilização é um dos primeiros temas a serem estudados.

Depois, temos que buscar identificar e relacionar esta flexibilização com o devido processo legal. Afinal de contas, flexibilizar implica em violar o devido processo legal ou é uma própria exigência dele?

A adoção da flexibilização do processo gera incremento no binômio garantia e eficiência. Cada vez mais este binômio quando visto de maneira antitética cria tensões na forma de ver o processo. A flexibilização, como se verá adiante, auxilia na tentativa de composição entre a eficiência e o garantismo, buscando compor fenômenos que devem, efetivamente, ser vistos de maneira integrada.

estarem inquestionavelmente vinculados aos direitos fundamentais e às normas constitucionais em geral, dispõem do poder de tomar livremente suas decisões mesmo em flagrante desrespeito à vontade expressa do constituinte. Com efeito, como bem lembra Luís Roberto Barroso, mediante o reconhecimento de uma proibição de retrocesso está a se impedir a frustração da efetividade constitucional, já que, na hipótese de o legislador revogar o ato que deu concretude a uma norma programática ou tornou viável o exercício de um direito, estaria acarretando um retorno à situação de omissão (inconstitucional, como poderíamos acrescentar) anterior. Precisamente neste contexto, insere-se a também argumentação deduzida pelos votos condutores (especialmente do então Conselheiro Vital Moreira) do já referido leading case do Tribunal Constitucional de Portugal, versando sobre o Serviço Nacional de Saúde, sustentando que "as tarefas constitucionais impostas ao Estado em sede de direitos fundamentais no sentido de criar certas instituições ou serviços não o obrigam apenas a criá-los, obrigam também a não aboli-los uma vez criados", aduzindo que "após ter emanado uma lei requerida pela Constituição para realizar um direito fundamental, é interdito ao legislador revogar esta lei, repondo o estado de coisas anterior. A instituição, serviço ou instituto jurídico por ela criados passam a ter a sua existência constitucionalmente garantida. Uma nova lei pode vir a alterá-los ou reformá-los nos limites constitucionalmente admitidos (grifo nosso); mas não pode vir a extingui-los ou revogá-los." h) Os argumentos esgrimidos restam enrobustecidos por um fundamento adicional extraído do direito internacional, notadamente no plano dos direitos sociais, econômicos e culturais. Com efeito, de acordo com a arguta observação de Victor Abramovich e Christian Courtis, bem retomada, no Brasil, por André de Carvalho Ramos, a imposição (dever) de uma progressiva implementação efetiva da proteção social por parte dos Estados implica uma implícita vedação de retrocesso em relação aos direitos sociais já concretizados." SARLET, Ingo Wolfgang. A eficácia do direito fundamental à segurança jurídica: dignidade da pessoa humana, direitos fundamentais e proibição de retrocesso social no direito constitucional brasileiro. Revista de Direito Constitucional e Internacional, n. 57, p. 5, São Paulo, RT, out. 2006. 


\section{CONCLUSÃO}

O trabalho apresentado tentou compreender como as mudanças da pósmodernidade influenciam o processo penal e, como estas mudanças afetam nossa forma de encará-lo.

Temos um processo eminentemente pautado pelos ideais iluministas: é dizer, temos um processo pautado pelo devido processo legal, pela publicidade, pelo contraditório e pela ampla defesa. No entanto, se é verdade que estas garantias encontramse positivadas em nosso texto constitucional, também é verdade que elas acabam por não atingir os processos e, assim, assegurar a vida dos indivíduos a quem destinam-se.

O descolamento do positivismo jurídico da práxis acaba por evidenciar que a proteção dos indivíduos não pode ser garantida unicamente pela legislação. Aliás, ao contrário, esta constatação serve para demonstrar que as leis, por si só, não são garantia de um processo justo.

Ao mesmo tempo em que foi demonstrado que as leis por si só não são garantias de um processo justo, também demonstrou-se que o processo justo deve ser buscado por todos aqueles que atuam processualmente.

As conclusões apresentadas encontram-se ao logo do trabalho. Contudo, serão apresentadas a seguir em apertada síntese as principais conclusões, o que não dispensa a leitura do trabalho para sua melhor compreensão.

Em apertada síntese, as conclusões são as seguintes:

1 - As transformações pelas quais passam a sociedade são tão rápidas que geram dificuldades para o legislador regulá-las com a necessária eficiência e, assim, há necessidade do estabelecimento de padrões normativos para a solução das questões jurídicas que surgem com estas mudanças, sem contudo, que haja desrespeito aos direitos humanos. 
2 - A globalização incrementa a relação entre os países, produz aumento da cooperação jurídica e, por isso, gera fluidez nos sistemas jurídicos, constituindo-se em fator de flexiblização.

3 - Embora vista por alguns como fenômeno estritamente econômico, o sentido da globalização é mais amplo: abarca tanto o fenômeno econômico quanto o fenômeno cultural.

4 - A crise no conceito de soberania conduz a mudança em seu paradigma, caminhando para a flexibilização. O paradigma anterior, amparado na desconfiança, base para a sustentação de um poder ilimitado dos Estados, não se motra mais como adequado e não corresponde à realidade mundial, sendo necessária sua superação, caminhando-se em direção ao paradigma da confiança.

5 - O paradigma da confiança conduz o Estado a ampliar seu alcance. $\mathrm{O}$ Estado Constitucional Cooperativo confia no sistema internacional e nos demais Estados. $\mathrm{O}$ fato de seu fundamento repousar no respeito aos direitos humanos facilita este mútuo reconhecimento e tornam mais seguras as bases de relacionamento entre os Estados que não mais possuem motivos para desconfiar de outros sistemas jurídicos.

6 - A flexibilização se manifesta na tecnologia por conta da velocidade das mudanças e pelas novas formas de interação entre as pessoas. As mudanças são tão rápidas e tão profundas que alteram diariamente a forma da relação dos indivíduos com o mundo e com as outras pessoas.

7 - O Direito deve refletir o mundo que o cerca, a sociedade em que vivemos. Um processo alheio à sociedade e aos seus valores é um processo que carece de legitimidade. O processo é a manifestação dos valores da sociedade.

8 - A flexibilização gerada no processo penal deve ser vista, contudo, com cuidado para que não sejam abandonadas as garantias criando-se um sistema sem qualquer proteção ao indivíduo.

9 - Com relação aos direitos fundamentais de resistência, percebe-se que a fluidez no processo deve ter limites; limites estes que não podem ferir de morte os direitos de resistência, especialmente em nome das novas tecnologias. 
10 - No Direito processual a flexibilização terá o mesmo sentido empregado nos demais ramos do Direito: tornar maleável a norma processual para as situações exigidas no caso concreto.

11 - Nota-se que existe clara tendência na utilização da flexibilização nos países da Europa continental. As alterações legislativas pelas quais passaram estes países demonstram este caminhar para a flexibilização.

12 - O Brasil segue de maneira predominante a tradição continental de sistema processual rígido. Em sua estrutura originária, nosso Código de Processo Penal tinha estrutura marcadamente rígida.

13 - Tem havido processos de flexibilização no Direito brasileiro: as medidas cautelares pessoais, a atenuação do sistema das nulidades e da análise do prejuízo e a admissibilidade do uso da prova ilícita são algumas formas de flexibilização.

14 - A flexibilização pode dar-se em sentido amplo ou em sentido estrito. Em sentido amplo, decorre da utilização dos mecanismos da regra de exceção, da interpretação extensiva e da equidade. A flexibilização em sentido estrito pode ocorrer em três planos: legislativo, judicial e consensual.

15 - São três os parâmetros para que se possa fazer a flexibilização do processo: a) legalidade, b) proporcionalidade e c) razoabilidade. Estes parâmetros são analisados de maneira escalonada.

16 - A análise da legalidade significa que o juiz deve analisar se há permissão expressa ou se há o silêncio da lei. Em ambas as situações será possível a flexibilização. Quando há permissão, em regra, o legislador fixa os critérios de flexibilização e o juiz deve atuar em conformidade com eles. Em caso de silêncio da lei, se o juiz, para adaptar a lei ao caso concreto, concluir pela necessidade de flexibilização, isso nunca poderá representar um desrespeito flagrante ao espírito da norma mas, excepcionalmente o seguimento do caminho inferido pelo ordenamento como um todo, será necessário para a solução adequada e justa.

17 - Se houver vedação da lei, somente poderá haver flexibilização caso o magistrado reconheça a inconstitucionalidade desta vedação. 
18 - A proporcionalidade é aplicada por meio de seus subprincípios: adequação, necessidade e proporcionalidade em sentido estrito.

19 - A medida de flexibilização será adequada sempre que estimule a obtenção do fim pretendido - adequação qualitativa -, devendo sua duração ou intensidade ser condizente com a sua finalidade - adequação quantitativa. Da mesma forma, a medida deve ser dirigida a um indivíduo sobre o qual incidam as circunstâncias exigidas para sua atuação - adequação subjetiva.

20 - O subprincípio da necessidade significa que uma medida é necessária quando não há outras que produzam resultado de igual intensidade e que violem menos direitos fundamentais.

21 - No caso de hard case, então haverá a incidência dos três subprincípios da proporcionalidade: necessidade, adequação e proporcionalidade em sentido estrito. Aqui, tem-se o sopesamento entre a intensidade da restrição ao direito fundamental atingido e a importância da realização do direito fundamental colidente e que justifica a adoção da medida restritiva.

22 - A opção escolhida pelo magistrado, ainda que não viole a legalidade ou a proporcionalidade não pode violar o princípio da razoabilidade. Aqui é adotada a posição que ficou conhecida como Teste de Wednesbury: se uma decisão é irrazoável de forma que nenhum administrador razoável a tomaria, então ela não pode ser aceita.

23 - A atuação do juiz irá variar conforme trate-se de flexibilização legislativa ou de flexibilização judicial.

24 - Quando tratar de flexibilização legislativa, a decisão pela flexibilização já foi tomada pelo legislador, cabendo ao juiz decidir por qual caminho seguir. Vale dizer, a escolha pela flexibilização já foi feita, resta ao juiz decidir qual o conteúdo do ato a ser flexibilizado, de forma que parte-se direto para a escolha do juiz entre as possíveis decisões apontadas pelo legislador.

25 - No caso de flexibilização legislativa, podem surgir duas situações distintas para o magistrado quanto aos critérios. Na primeira delas, o legislador já indica os parâmetros para a flexibilização; hipótese que o magistrado deverá necessariamente fundamentar sua decisão com base nestes parâmetros. Na segunda situação, o legislador 
não indica os parâmetros da flexibilização. Aqui o magistrado não precisará analisar a legalidade, visto que a lei já determinou a flexibilização, devendo então, apenas, pautá-la pelos critérios da proporcionalidade e da razoabilidade.

26 - Com a flexibilização é possível que seja privilegiado o interesse da acusação, da defesa ou, a depender da situação, de ambas as partes. A flexibilização pode, portanto, atingir todos os interesses envolvidos no processo.

27 - No caso da flexibilização em favor da defesa, a situação mostra-se de mais fácil admissão. É que o princípio do favor rei justifica a adoção de medidas que possibilitem a ampliação dos direitos e garantias individuais.

28 - Mais problemática é a flexibilização em favor da acusação. Neste caso, também é possível a flexibilização do processo para atender interesses da acusação quando as peculiaridades do caso concreto exigirem. A eficiência de que o sistema deve ser dotado justifica que a flexibilização também possa ocorrer para beneficiar os interesses da acusação quando se fizer necessário seu uso.

29 - Contudo, é preciso que seja superada a dicotomia entre os interesses da acusação e os interesses da defesa de forma que ambos coexistam de maneira harmônica.

30 - A flexibilização não pode representar violação aos direitos humanos, sob pena de indevido retrocesso das conquistas da humanidade. Da mesma forma não pode configurar desrespeito ao devido processo legal.

31 - Os direitos humanos possuem três importantes características: universalidade, irrevogabilidade e complementaridade.

32 - A questão liga-se à vedação do retrocesso. Entende-se que não há incompatibilidade com a flexibilização tendo em vista os parâmetros apresentados para sua efetivação.

33 - O direito fundamental pode ser restringido, mas jamais aquém de seu núcleo essencial. Adota-se a teoria do conteúdo essencial relativo.

34 - Toda restrição que passe pelo teste da proporcionalidade não atinge o conteúdo essencial e, portanto, é restrição constitucional. 
35 - Tendo em vista a existência de parâmetros claros e concretos, não poderá o magistrado flexibilizar o processos se as Cortes Internacionais de Direitos Humanos já se manifestaram pela impossibilidade de realizar o ato que se pretenda eventualmente fazer.

36 - A análise da vedação do retrocesso em relação ao devido processo legal deve ser feita à luz da jurisprudência da Corte Interamericana de Direitos Humanos e, neste ponto, a Corte não apresenta restrição à flexibilização.

37 - Da mesma forma, também a Corte tem entendido que os direitos humanos representam um limite à atividade do Estado e, assim, deve haver a observância das garantias mínimas do devido processo legal para aqueles que se encontram na posição de réus em ação penal.

38 - O devido processo legal representa a correta aplicação das leis dentro deste marco de respeito mínimo aos direitos fundamentais e da dignidade da pessoa humana. Faz-se necessária a observância de garantias para que seja reconhecido o devido processo legal, não havendo relação de necessariedade com a observância de cada um dos atos específicos do processo.

39 - Uma vez que no parâmetro da legalidade está inserido o respeito aos direitos humanos por meio das decisões da Corte Interamericana e das decisões do Supremo Tribunal Federal não há que se falar em violação dos direitos humanos e do devido processo legal. A observância destes parâmetros impede que haja a violação da cláusula de vedação do retrocesso permitindo ao magistrado conduzir a decisão para as necessidades que os casos concretos possam impor.

40 - A macro-criminalidade é tema que causa grande preocupação aos Estados. Dados seus efeitos deletérios na sociedade, tem recebido tratamento legislativo diferenciado em decorrência de orientação da Organização das Nações Unidas. A preocupação aqui centra-se, notadamente, nas questões atinentes ao terrorismo e à criminalidade organizada.

41 - As Cortes Internacionais de Direitos Humanos já se manifestaram em alguns casos de flexibilização legislativa. O que verifica-se destes julgamentos é que algumas medidas restritivas podem ser tomadas por parte do Estado no trato da criminalidade mais grave ou organizada, mas há um limite para estas restrições. 
42 - No que se refere às medidas cautelares pessoais, não se trata, mediante flexibilização, de aceitar a adoção de medidas cautelares atípicas, mas na verdade de flexibilização no sentido empregado no trabalho, ou seja, por meio da extensão das medidas existentes ou sua restrição, não sendo possível a criação de medidas novas.

43 - Não pode o julgador criar novas medidas cautelares distintas das previstas em lei; no entanto, isso não significa que sua execução não possa ser flexibilizada.

44 - Os artigos 310 e 321 do Código de Processo Penal criaram mecanismo de flexibilização legislativa dirigida ao juiz. São mecanismos de flexibilização pois podem ser tomadas várias medidas, como a decretação da prisão preventiva, a liberdade provisória ou medidas diversas da prisão.

45 - A necessidade e a adequação são critérios norteadores inseridos no parâmetro geral da proporcionalidade, analisados anteriormente. Os demais parâmetros apresentados pelo legislador são concretizações do parâmetro geral da razoabilidade.

46 - Utilizando-se dos parâmetros de flexibilização desenvolvidos (legalidade, proporcionalidade e razoabilidade) tem-se que a flexibilização é admitida para que o assistente de acusação possa pedir a aplicação das medidas cautelares pessoais diversas da prisão.

47 - A flexibilização autoriza a restrição temporal das medidas cautelares pessoais diversas da prisão. Da mesma forma que a prisão, as medidas cautelares pessoais diversas da prisão constituem-se em limitação da liberdade do indivíduo antes do trânsito em julgado e, por isso, não podem ser prolongadas de maneira indefinida no tempo.

48 - As medidas cautelares pessoais menos graves, também ostentam caráter cautelar e, portanto, não podem perdurar indefinidamente antes do trânsito em julgado. O prolongamento indevido do processo no tempo irá gerar, forçosamente, a revogação da medida cautelar imposta.

49 - No que se refere à prisão preventiva, os parâmetros de flexibilização permitiriam o afastamento da limitação do artigo 313, I, do Código de Processo Penal, de forma que poderá a prisão preventiva ser decretada independentemente da quantidade de pena cominada, em caráter excepcional. 
50 - E possível com a flexibilização estender a incidência do artigo 319 do Código de Processo Penal para determinar o comparecimento do réu em outro local público que não o fórum.

51 - Em princípio, descumprida a medida de prisão domiciliar caberá a utilização de medida cautelar alternativa à prisão preventiva como forma de dar efetividade à prisão domiciliar. Em caráter excepcional, é possível imaginar o uso da flexibilização de forma a restringir a incidência do artigo 318 do Código de Processo Penal afastando-o e, então, revogar a prisão domiciliar e determinar o recolhimento ao cárcere. A flexibilização não é a regra e somente será utilizada em situações excepcionais.

52 - A flexibilização autoriza a possibilidade de arrolar testemunhas fora da resposta à acusação quando a defesa somente tomou contato com o acusado no momento da audiência de instrução, debates e julgamento.

53 - A flexibilização pode ocorrer para que os atos a serem realizados por meio de carta precatória sejam substituídos para que o juiz da causa os pratique em videoconferência, mostra-se adequada, necessária e razoável.

54 - Razões como a complexidade da causa ou mesmo do material probatório podem justificar a ampliação do prazo das alegações finais pelo magistrado a fim de melhor propiciar às partes, acusação e defesa, o exercício de sua função, antes de afastar quem representa a parte.

55 - A aplicação da teoria das private searches gera a flexibilização da obtenção da prova no meio virtual e conduz a melhor proteção da intimidade e da eficiência do processo.

56 - Utiliza-se o teste criado pela Suprema Corte Norte-Americana. O teste consiste em uma análise ampla da expectativa de privacidade, tanto do ponto de vista do indivíduo quanto da sociedade: a) expectativa subjetiva de privacidade - consiste na opinião do indivíduo de que possui, naquela situação, privacidade; b) expectativa objetiva de privacidade - consiste na expectativa de privacidade reconhecida pela sociedade.

57 - A teoria das private searches flexibiliza a forma de verificação da intimidade e sua proteção, de forma a compor o binômio garantismo e eficácia do processo ampliando a atuação de ambos. 
58 - Por meio da flexibilização, com base em interpretação extensiva, é admissível a incidência de algum dos incisos do artigo 581 do Código de Processo Penal para a decisão sobre medidas cautelares. Trata-se de situação similar à do indeferimento do pedido de prisão preventiva. Em suma, é cabível o Recurso em Sentido Estrito previsto no artigo 581, inciso V do Código de Processo Penal.

59 - O artigo $4^{\mathrm{o}}$ da Constituição Federal estabelece o dever de cooperar, conforme se depreende dos princípios nele expostos: a) princípio da autodeterminação dos povos (inciso III); b) princípio da igualdade entre os Estados (inciso V); c) princípio da solução pacífica dos conflitos (inciso VII); d) princípio da integração (parágrafo único do $\left.\operatorname{artigo} 4^{\circ}\right)$.

60 - Forma de flexibilização na cooperação internacional veio com o auxílio direto. É uma das formas de cooperação jurídica internacional, além da carta rogatória, da extradição e da homologação de sentença estrangeira.

61 - A Cooperação Jurídica, seja pela via da carta rogatória, seja pela via do auxílio direto, está sujeita a limites. Cooperar não significa admitir todo e qualquer pedido feito por outro Estado. Isso porque deve-se reconhecer como válida algumas divergências entre os sistemas. Por outro lado, escolher divergências pontuais entre os sistemas para evitar a cooperação foge do ideal do Estado Constitucional Cooperativo.

62 - A experiência internacional mostra-se fundamental para que sejam melhor compreendidos os limites da cooperação. Da posição dos países estudados, fica evidente que há crescente preocupação com a proteção dos direitos fundamentais.

63 - Nas hipóteses de Cooperação Internacional, deve um país analisar se, ao cooperar, estará permitindo que de maneira indireta sejam violados direitos fundamentais que exponham o Estado a possíveis sanções pelas Cortes. Para que se possa cooperar nas hipóteses em que haja diferença legislativa entre os sistemas, devemos observar os três parâmetros da flexibilização: 1- legalidade; 2 - proporcionalidade; 3 - razoabilidade. 


\section{REFERÊNCIAS BIBLIOGRÁFICAS}

Alarcón, Pietro de Jesús. Reflexões sobre o processo e constituição: a tarefa transformadora do processo e a efetividade do estado. Revista do Instituto dos Advogados de São Paulo, p. 224, São Paulo, GRÁFICA/EDITORA, 2006.

ALEXY, Robert. Teoría del discurso y derechos humanos. Bogotá/Colômbia: Universidad Externado de Colombia, 1995.

. Teoria dos direitos fundamentais. Trad. Virgílio Afonso da Silva. São Paulo: Malheiros Editores Ltda, 2008.

ANDOLINA, Ítalo. Il tempo e il processo. RePro, n. 126, p. 259, São Paulo, RT, 2009.

AndRAdE Junior, Luis Carlos Vilas Boas. Limites da (promoção da) igualdade. Revista de Direito Constitucional e Internacional, v. 77, São Paulo, RT, out. 2011.

ARAÚJO, Nadia de. A importância da cooperação jurídica internacional para a atuação do estado brasileiro no plano interno e internacional. In: CASELla, Paulo Borba; RAMOS, André de Carvalho (coords.). Direito internacional: homenagem a Adherbal Meira Mattos. São Paulo: Quartier Latin, 2009.

Direito internacional privado: teoria e prática brasileira. 4. ed. Rio de Janeiro: Renovar, 2008.

. Medidas de cooperação intejurisdicional no mercosul. RePro, n. 123, p. 06, São Paulo, RT, mai. 2005.

ÁviLA, Humberto. O que é o devido processo legal? RePro, n. 163, p. 50, São Paulo, RT, 2008.

BADARÓ, Gustavo Henrique Righi Ivahy. As novas medidas cautelares alternativas à prisão e o alegado poder geral de cautela no processo penal: a impossibilidade de decretação de medidas atípicas. Revista do Advogado, n. 113, ano XXXI, p. 80, São Paulo, Associação dos Advogados de São Paulo,2011 
BADARÓ, Gustavo Henrique Righi Ivahy.Processo Penal. Rio de Janeiro: Campus: Elsevier, 2012.

BASSO, Maristela. Curso de direito internacional privado. São Paulo: Atlas, 2009.

BAUMAN, Zygmunt. A sociedade individualizada: vidas contadas e histórias vividas. Rio de Janeiro: Jorge Zahar, 2008.

. Globalização: as consequências humanas. Rio de Janeiro: Jorge Zahar Ed., 1999.

BECHARA, Fabio R. Cooperação jurídica internacional em matéria penal: eficácia da prova produzida no exterior. São Paulo: Saraiva, 2011.

BERARDI, Luciana Andrea Accorsi. Interpretação constitucional e o princípio do devido processo legal. Revista de Direito Constitucional e Internacional, n. 54, p. 210, São Paulo, RT, 2006.

BETTI, Emilio. Interpretação da lei e dos atos jurídicos. São Paulo: Martins Fontes, 2007.

BETTIOL, Giuseppe. Instituições de Direito e processo penal. Coimbra: Coimbra Ed, 1974.

BIDART, Adolfo Gelsi. Tutela Procesal 'Diferenciada'. RePro, n. 44, p. 100, São Paulo, RT, 1986.

BINDER, Alberto M. Introdução ao direito processual penal. Rio de Janeiro: Lumen Juris, 2003.

BITTAR, Eduardo C. B. O direito na pós-modernidade (e reflexões frankfurtianas). 2. ed. atual. e ampl. Rio de Janeiro: Forense Universitária, 2009.

BobBIO, Norberto. Teoria da norma jurídica. São Paulo: EDIPRO, 2001.

BRIGGS, Arthur. Cartas rogatórias internacionais. Rio de Janeiro: Imprensa Nacional, 1913.

Brun, I. R; Soler, J. M. R.; GonZÁles, M. R. Derecho procesal penal. Pamplona: Gobierno de Navarra, 2006.

Bueno, José Antonio Pimenta. Direito internacional privado e applicação de seus princípios com referencia ás leis particulares do Brazil. Rio de Janeiro: Typographia Imp. e Const. de J. Villeneuve E C., 1863. 
Calamandrei, Piero. La relatività del concetto di azione. Rivista di Diritto Processuale Civile, v. XVI, parte 1, 1939.

Campuzano, Alfonso de Julios. Constitucionalismo em tempos de globalização. Porto Alegre: Livraria do Advogado Editora, 2009.

CASSESE, Antonio. Existe um conflito insuperável entre soberania dos Estados e justiça penal internacional? In: CAssese, Antonio; Delmas-Marty, Mireille (coords.). Crimes internacionais e jurisdições internacionais. São Paulo: Manole, 2003.

CASTELls, Manuel. A galáxia da internet: reflexões sobre a internet, os negócios e a sociedade. Rio de Janeiro: Zahar, 2003.

CAstilho, Ela Wiecko V. de. Cooperação internacional na execução da pena: a transferência de presos. RBCCRIM, p. 233, São Paulo, RT, 2008.

CASTRO, Carlos Eugênio San Martín. A privação cautelar da liberdade no processo penal peruano. In: Ambos, Kai; ChOUKR, Fauzi Hassan. Processo penal e estado de direito. Campinas: Edicamp, .

Catena, Víctor Moreno. Garantía de los derechos fundamentales en la investigación penal. Cuadernos de Doctrina y Jurisprudencia Penal, año IV, n. 8-A, Ad-Hoc, Buenos Aires - Arg., 1998.

Cavallero, María del Pilar. Análisis del art. 319 del CPPN. In: Chiara DíAz, Carlos Alberto; HoRACIO, Daniel (coords.). Garantías, medidas cautelares e impugnaciones en el proceso penal. Rosario/Arg.: Editorial Jurídica Nova Tesis, 2005.

CAvalli, Cássio Machado. A compreensão jurídica do dever de razoabilidade. Revista de Direito Constitucional e Internacional, n. 50, p. 220, São Paulo, RT, 2005.

ChIARloni, Sérgio. Riflessioni microcomparative su ideologie processuali e accertamento della verità. RePro, n. 176, p. 105, São Paulo, RT, 2009.

CORRÊA, Cristiane da Rocha. O princípio do contraditório e as provas irrepetíveis no inquérito policial. RBCCrim, n. 60, p. 223, São Paulo, RT, mai. 2006.

Costa, Domingos Barroso da. Da modernidade à pós-modernidade, do positivismo ao pós-positivismo sobre a exposição da crise de legitimidade do sistema penal brasileiro pelas transformações da sociedade e do direito. RBCCrim, n. 94, São Paulo, RT, jan. 2012. 
Costa, José de Faria. Linha de direito penal e de filosofia, alguns cruzamentos reflexivos. Coimbra: Coimbra Editora, 2005.

. O fenómeno da globalização e o direito penal econômico. RBCCrim. n. 34, São Paulo, RT, abr. 2001.

Cox, Archibald. The Supreme Court 1965 Term--Foreword: constitutional adjudication and the promotion of human rights. Harvard Law Review, v. 80/91, 1966-1967. Disponível em: <http://home.heinonline.org/>. Acesso em: 30 de outubro de 2012.

DEU, Teresa Armenta. Estudios sobre el processo penal. Santa Fé/Argentina: RubinzalCulzoni, 2008.

Di MAIS, Gerardo Ramon; OBLIGADO, Daniel Horacio. Las nulidades en el processo penal. 2. ed. Lima: Ediciones Juridicas del Centro: 2011.

Dimoulis, Dimitri; MARTINS, Leonardo. Teoria geral dos direitos fundamentais. 2. ed. São Paulo: RT, 2009.

Dolinger, Jacob. Direito internacional privado.Parte geral. 9. ed. São Paulo: Renovar, 2008 .

DonNELly, Jack. Cultural relativism and universal human rights. Human Rights Quaterly, v. 6, n. 4, nov. 1984. Disponível em: <http://home.heinonline.org/>. Acesso em: 25 de agosto de 2012.

DoYLE, Charles. Extradition to and from the United States. Nova York: Nova Science Publishers, 2008.

DUlClERC, Emir. Princípios constitucionais relativos à prisão processual no Brasil: o problema da inefetividade. Diagnóstico crítico e alternativas de superação. RBCCrim, $\mathrm{n}$. 64, São Paulo, RT, jan. 2007.

FALLON JR., Richard H. Judicially manageable standards and constitutional meaning. Harvard Law Review, v. 119, 1274. Disponível em: <http://home.heinonline.org/>. Acesso em: 20 de fevereiro de 2012.

FERnANDES, Antonio Scarance. Processo penal constitucional. 7. ed. São Paulo: RT, 2012. ; Grinover, Ada Pellegrini; Gomes Filho, Antonio Magalhães. Recursos no processo penal: teoria geral dos recursos, recursos em espécie, ações de impugnação. 4. ed. São Paulo: RT, 2005. 
Funções e limites da prisão processual. RBCCrim, v. 64, p. 239, São Paulo, RT, jan. 2007.

O equilíbrio entre a eficiência e o garantismo e o crime organizado. RBCCrim, $\mathrm{n}$. 70, São Paulo, RT, jan. 2008.

Teoria geral do procedimento e o procedimento no processo penal. São Paulo: RT, 2005.

FERRAJOLI, Luigi. A soberania no mundo moderno: nascimento e crise do estado nacional. 2. ed. São Paulo: Martins Fontes, 2007.

FOLADOR, Patricia Micheli. Os princípios orientadores da convenção europeia de direitos humanos. Revista de Direito Constitucional e Internacional, v. 79, , São Paulo, RT, abr. 2012

GAJARDONI, Fernando da Fonseca. Flexibilização procedimental: um novo enfoque para o estudo do procedimento em matéria processual. São Paulo: Editora Atlas, 2008.

GARCíA, Gerardo Nicolás. Hacia lá abolición de lá prisión preventiva. Pensamento penal del Sur, Publicación del Área Penal de las Faculdades de Derecho de las Universidades Nacionales del Comahue, del Sur y de La Pampa, 2006/II, Fabián J. Di Plácido Editor.

GARCIA, Maria. Fundamentalidade e direitos fundamentais: o $\S 2 .^{\circ}$ do $\operatorname{artigo} 5 .^{\circ}$ DA CF/1988. Direitos humanos e direitos e garantias fundamentais. Revista de Direito Constitucional e Internacional, v. 67, São Paulo, RT, 2009.

GARCíA, Nicolás Rodríguez. Cooperação jurídica penal e Ministério Público europeu. Revista dos Tribunais, n. 836, p. 456, São Paulo, RT, 2005.

GIDDENS, Anthony. Sociologia. 4. ed. Porto Alegre: Artmed, 2005.

GIMENES, Marta Cristina Cury Saad. Defesa técnica dos presos em flagrante delito. Boletim IBCCRIM 173, São Paulo, IBCCRIM, abr. 2007.

Direito ao silêncio na prisão em flagrante. In: MALAN, Diogo; PRADO, Geraldo (coord.). Processo penal e democracia: estudos em homenagem aos 20 anos da Constituição da República de 1988. Rio de Janeiro: Editora Lumen Juris, 2009.

Gomes FILHo, Antonio Magalhães. A motivação das decisões penais. São Paulo: RT, 2001. 
; GrinOVER, Ada Pellegrini; FernANDES, Antonio Scarance. Recursos no processo penal: teoria geral dos recursos, recursos em espécie, ações de impugnação. 4. ed. São Paulo: RT, 2005.

GonzÁles, M. R.; Brun, I.R; Soler, J. M. R. Derecho procesal penal. Pamplona: Gobierno de Navarra, 2006.

GREVI, Vittorio. Compendio di procedura penale. 5. ed. Padova: CEDAM, 2010.

GrINOVER, Ada Pellegrini. As garantias processuais na cooperação internacional em matéria penal. RePro, $n$. 81, p. 160, São Paulo, RT, 1996.

; Gomes FILHo, Antonio Magalhães; FeRnAndes, Antonio Scarance. Recursos no processo penal: teoria geral dos recursos, recursos em espécie, ações de impugnação. 4. ed. São Paulo: RT, 2005.

GROSSMAN, Gene M. e KATZ, Michael L. Plea bargaining and social welfare. The American Economic Review, vol. 73, n 4, p. 749, 1983.

GuERRA, Willis Santiago. A dimensão processual dos direitos fundamentais. RePro, n. 87, p. 166, São Paulo, RT, 1997.

HABER, Carolina Dzimidas. A produção da prova por videoconferência. RBCCrim, n. 82, São Paulo, RT, jan. 2010.

HÄBERLE, Peter. Estado constitucional cooperativo. Rio de Janeiro: Renovar, 2007.

HaRvey, David. Condição pós-moderna. 7. ed. São Paulo: Edições Loyola, 1998.

Hathaway, Oona A. Do human rights treaties make a difference? Yale Law Review, v. 111, p. 2020-2022, 1935, 2001-2002. Disponível em: <http://home.heinonline.org/>. Acesso em: 05 de agosto de 2011.

JACKSON, Vicki C. Constitucional comparisons: convergence, resistance, engagement. Harvard Law Review, n. , p. 109, 2007. Disponível em: <http://home.heinonline.org/>. Acesso em: 03 de março de 2011.

KERR, Orin S. An equilibrium-adjustment theory of the fourt amendment. Harvard Law Review, n. 476, 2011. Disponível em: <http://home.heinonline.org/>. Acesso em: 03 de março de 2011.

Searches and seizures in a digital world. Harvard Law Review, v. 119, p. 531, 2005. 
KREMPEL, Luciana Rodrigues. Os recursos em processo penal: relevância e determinação tendo em vista a ordem jurídica constitucional e processual penal em Portugal. RBCCrim, n. 45, p. 59, São Paulo, RT, out. 2003.

KUTNER, Luis. World habeas corpus for international man: a credo for international due process of law. University of Detroit Law Review, v. XXXVI, n. 3, 1959. Disponível em: <http://home.heinonline.org/>. Acesso em: 05 de abril de 2011.

LAFER, Celso. A reconstrução dos direitos humanos, um diálogo com o pensamento de Hannah Arendt. São Paulo: Companhia das Letras Editora, 1988.

LÉVY, Pierre. O futuro da internet: em direção a uma ciberdemocracia planetária. São Paulo: Paulus, 2010. O que é o virtual? São Paulo: Ed. 34, 1996.

LEONE, Giovanni. Tratado de Derecho Procesal Penal, volume I - Doctrinas Generales. Buenos Aires: Ediciones Juridicas Europa-America, 1989.

LEVY, Pierre.Cibercultura. São Paulo: Ed. 34, 1999.

LimA, Maria Rosynete Oliveira. Devido processo legal. Porto Alegre: Sergio Antonio Fabris Editor, 1999.

LOPES JÚNIOR, Aury Celso Lima. Direito ao processo penal no prazo razoável. RBCCrim, n. 65, p. 205, São Paulo, RT, mar. 2007.

LÖWEnthal, Paulo Friedrich Wilhelm. As origens do devido processo legal substancial e o seu desenvolvimento na Suprema Corte Norte-Americana. Revista de Direito Constitucional e Internacional, n. 75, p. 283, São Paulo, RT, 2001.

LYRA, José Francisco Dias da Costa. Direito penal, constituição e hermenêutica: pela superação do positivismo jurídico e a possibilidade do acontecer do direito num ambiente de neoconstitucionalismo. RBCCrim, n. 91, São Paulo, RT, jul. 2011.

MADRUGA, Antenor. O Brasil e a jurisprudência do STF na idade média da cooperação jurídica internacional. RBCCrim, p. 291, São Paulo, RT, 2005.

Martini, Carlo Maria; Zagrebelsky, Gustavo. La exigencia de justicia. Madrid: Miguel Carbonell, 2006.

MARTINS, Leonardo; Dimoulis, Dimitri. Teoria geral dos direitos fundamentais. 2. ed. São Paulo: RT, 2009. 
MAIA, Maurilio Casas. A cooperação solidária e a desigualdade compensadora como mandamento constitucional brasileiro e imperativo do direito internacional do desenvolvimento. Revista de Direito Constitucional e Internacional, v. 79, São Paulo, RT, abr. 2012.

MaIER, Julio B. J. Derecho Procesal Penal. II Parte General Sujetos procesales. Buenos Aires: Editores Del Puerto, 2003.

MaXimiLiano, Carlos. Hermenêutica e aplicação. Rio de Janeiro: Forense, 1995.

Melchior, Antonio Pedro. Juiz-Secretário de segurança pública. Breve ensaio sobre o neoconstitucionalismo e o ativismo judicial em matéria criminal na realidade periférica judge secretary for public safety. A brief overview about neo-constitutionalism and legal activism in criminal matter in the reality of the outskirts. RBCCrim, n. 96, São Paulo, RT, mai. 2012.

Menezes, Wagner. Os princípios no direito internacional. In: CASELla, Paulo Borba; Ramos, André de Carvalho (coords.). Direito internacional: homenagem a Adherbal Meira Mattos. São Paulo: Quartier Latin, 2009.

MichAELS, Ralf. The new european choice of law revolution. Tulane Law Review, v. 82, p. 1607-1637, 2008. Disponível em: 〈http://home.heinonline.org/>. Acesso em: 04 de maio de 2011.

MiCHAUD, Jean. F. Chronique du parquet et de l'instruction. Revue de science criminelle et de droit pénal compare. Nouvelle Série, no 1, Éditions Sirey, 1972.

MiLLER, Arthur S. An affirmative thrust to due process of law? The George Washington Law Review, v. 30, n. 3, 1962. Disponível em: 〈http://home.heinonline.org/>. Acesso em: 15 de julho de 2011.

MONTORO, Marcos André Franco. Flexibilidade do procedimento arbitral. (Tese de Doutorado). São Paulo: Universidade de São Paulo, Curso de Direito, 2010.

Moraes, Maurício Zanoide de. Presunção de inocência no processo penal brasileiro: análise de sua estrutura normativa para a elaboração legislativa e para a decisão judicial. Rio de Janeiro: Editora Lumen Juris, 2010. 
Análise judicial da prisão em flagrante: por uma abordagem sistêmicoconstitucional. Revista do Advogado. (A Reforma do Processo Penal), ano XXXI, n. 113, p. 97 , set. 2011.

MoreIRA, Eduardo Ribeiro. A teoria das restrições dos direitos fundamentais. Revista de Direito Constitucional e Internacional, n. 69, p. 90, São Paulo, Editora Revista dos Tribunais, 2010

Moschen, Valeska Raizer Borges. A solução europeia para a competência internacional. RePro, n. 192, p. 307, São Paulo, RT, 2011.

MuRCHISON, Matthew. Extradition's Paradox: duty, discretion and rights in the world of non inquiry. Stanford Journal of International Law, p. 300, 2007.

NovaIS, Jorge Reis. Direitos fundamentais: trunfos contra a maioria. Coimbra: Coimbra Editora, 2006.

OBLIGADO, Daniel Horacio; Di MAIS, Gerardo Ramon. Las nulidades en el processo penal. 2. ed. Lima: Ediciones Juridicas del Centro: 2011.

PIOVeSAn, Flávia. Direitos humanos - visões contemporâneas. São Paulo: Associação Juízes para Democracia, 2001.

; GOMES, Luiz Flávio. O sistema interamericano de proteção dos direitos humanos e o direito brasileiro. São Paulo: RT, 2000.

Prigogine, Ilya. O fim das certezas: tempo, caos e as leis da natureza. São Paulo: Editora da Universidade Estadual Paulista, 1996.

PulIDO, Carlos Bernal. El principio de proporcionalidad y los derechos fundamentales. El principio de proporcionalidad como criterior para determinar el contenido de los derechos fundamentales vinculante para el legislador. 7. ed. Madrid: Centro de Estudos Políticos y Constitucionales, 2007.

. Teoria geral dos direitos humanos na ordem internacional. Rio de Janeiro: Renovar, 2005.

Processo internacional de direitos humanos: análise de apuração de violações dos direitos humanos e a implementação das decisões no Brasil. Rio de Janeiro: Renovar, 2002 . 
RAmos, André de Carvalho. Direitos humanos na integração econômica: análise comparativa da proteção de direitos humanos e conflitos jurisdicionais na União Europeia e Mercosul. Rio de Janeiro: Renovar, 2008.

. Processo internacional de direitos humanos: Análise de apuração de violações dos direitos humanos e a implementação das decisões no Brasil. Rio de Janeiro: Renovar, 2002 .

Direitos humanos em juízo, comentários aos casos contenciosos e consultivos da Corte Interamericana de direitos humanos e estudo da implementação dessas decisões no direito brasileiro. São Paulo: Max Limonad, 2001.

Ramos, Elival da Silva. Ativismo judicial, parâmetros dogmáticos. São Paulo: Saraiva, 2010.

RESCIA, Victor Manuel Rodríguez. El debido proceso legal y la convención americana sobre derechos humanos. Liber Amicorum. Héctor Fix-Zamudio, Secretaría de la Corte Interamericana de Derechos Humanos, San José, Costa Rica, 1998.

RESENDE, Tiago Souza de. A liberdade provisória como regra constitucional. In: EsTEVES, Heloísa Monteiro de Moura; PINTO, Felipe Martins; Resende, Sérgio Antônio de (coord.). Análise de precedentes criminais do Superior Tribunal de Justiça. Estudos em homenagem à Desembargadora Jane Ribeiro Silva. Belo Horizonte: Editora Atualizar, 2009.

RIBEIRO, Ludmila Mendonça Lopes. O tempo da justiça criminal nos EUA, Brasil e Portugal em uma perspectiva comparada. RBCCRIM, n. 91, São Paulo, RT, jul. 2011.

RICCIO, Giuseppe. Errore di calcolo sui termini massimi di custodia cautelare ed errore di interpretazione: una equipoarazione solo apparente. Rivista Italiana di Diritto e Procedura Penale, Nuova Serie, Anno XXXV, Dott. A. Giuffrè Editore, 1992.

RIONDATO, Silvio. Dal mandato d'arresto europeo al libro verde sulle garanzie alla constituzione europea: spunti sulle nuove vie di affermazione del diritto penale sostanziale europeo. Rivista Trimestale di Diritto penale dell'economia, anno XVII, n. 3-4, 2004. CEDAM.

RocA, Javier Garcia. Soberanía estatal versus integración Europea mediante unos derechos fundamentales comunes: cual es el margen de apreciación nacional? In: RocA, Javier Garcia; SÁNCHEZ, Pablo A. Fernandez (coords.). Integración europea a través de derechos 
fundamentales: de un sistema binário a outro integrado. Madrid: Centro de Estudios Políticos y Constitucionales, 2009.

Rodrigues, Anabela Miranda. A fase preparatória do processo penal - tendências na Europa. O caso português. RBCCrim, n. 39, São Paulo, RT, jul. 2002.

RODRÍGUEZ, Raúl Carnevali. Cuestiones fundamentales que el ordenamento comunitário propone a los derechos penales nacionales. RBCCrim, n. 40, p. 36, São Paulo, RT, out. 2002.

ROMANO, Mariaivana. Il diritto alla libertà nell'ordinamento spagnolo procedimento penale e misura detentiva. L'Indice Penale, Nuova Serie, anno VIII, n. 3, p. 1188, CEDAM, 2005.

RoSAS, Roberto. Devido processo legal: proporcionalidade e razoabilidade. Revista dos Tribunais p. 11, 2001.

RÜDIGER, Francisco. As teorias da cibercultura. Porto Alegre: Sulina, 2011.

SÁNCHEZ, Martín Alejandro. Inconstitucionalidad de la prisión preventiva. In: CHIARA DíAZ, Carlos Alberto; HoRACIO, Daniel. (coords.). Garantías, medidas cautelares e impugnaciones en el proceso penal. Rosario/Arg.: Editorial Jurídica Nova Tesis, 2005.

SANGUINÉ, Odone. Efeitos perversos da prisão cautelar. RBCCrim, v. 86, set. 2010.

A inconstitucionalidade do clamor publico como fundamento da prisão preventiva. In: SHECAIRA, Sérgio Salomão (coord.). Estudos criminais em homenagem a Evandro Lins e Silva. São Paulo: Editora Método, 2001.

SANTOS, Boaventura de Sousa. Os direitos humanos na zona de contato entre globalizações rivais. RBCCrim, n. 64,São Paulo, RT, jan. 2007.

SAntos, Juarez Cirino dos. 30 anos de vigiar e punir (Foucault). RBCCrim, n. 58, p. 289, São Paulo, RT, jan. 2006.

SARLET, Ingo Wolfgang. A eficácia dos direitos fundamentais. 8. ed. Porto Alegre: Livraria do Advogado Editora, 2007.

A eficácia do direito fundamental à segurança jurídica: dignidade da pessoa humana, direitos fundamentais e proibição de retrocesso social no direito constitucional brasileiro. Revista de Direito Constitucional e Internacional, n. 57, São Paulo, RT, out. 2006. 
SECHI, Paola. Liberta personale dell'imputato. Custodia cautelare. Detrazzione dalla pena inflita per alto reato. Condizioni. Rivista Italiana di Diritto e Procedura Penale, Nuova Serie, anno XXXI, Dott. A. Giuffrè Editore, 1988.

SERGI, Natália. El plazo de duracion del encarcelamiento preentivo segun el Tribunal de Casación Penal de la província de Buenos Aires. Revista de Derecho Penal y Procesal Penal, n. 6, Buenos Aires/Arg, LexisNexis, 2007.

SEvcenko, Nicolau. A corrida para o século XXI: no loop da montanha russa. São Paulo: Companhia das Letras, 2009.

SHECAIRA, Sério Salomão. Comentários ao acórdão 142.513/ES, Rel. Min. Nilson Naves. RBCCrim, n. 84, p. 417, São Paulo, RT, mai. 2010.

SiCHES, L. R. Tratado general de filosofia del derecho. 22. ed. México: Editorial Porrúa S.A., 1959.

SILVA, Danielle Souza Andrade e. A temporalidade específica da prisão preventiva: um mecanismo de conciliação entre garantias individuais e efetividade no processo penal. RBCCRIM, v. 62, p. 197, São Paulo, RT, set. 2006.

Silva, Ricardo Perlingeiro Mendes da. Auxílio direto, carta rogatória e homologação de sentença estrangeira. RePro, p. 287, São Paulo, RT, 2005.

Anotações sobre o anteprojeto de lei da cooperação jurídica internacional, Publicado em 2005. Disponível em: < www.uff.br/direito/artigos.htm>. Acesso em 10 de julho de 2010.

Silva, Virgilio Afonso da. O proporcional e o razoável. Revista dos Tribunais, n. 798, p. 29, São Paulo, RT, 2002.

Direitos fundamentais: conteúdo essencial, restrições e eficácia. São Paulo: Malheiros, 2010.

SOARES, Guido F. S. União Europeia, Mercosul e a proteção dos direitos humanos. In: PiOvesan, Flávia (coord.). Direitos Humanos, globalização econômica e integração regional: desafios do direito constitucional internacional. São Paulo: Max Limonad, 2002. RÜDIGER, Francisco. As teorias da cibercultura, perspectivas, questões e autores. Porto Alegre: Sulina, 2011. 
Soler, J. M. R; GonzÁles, M. R.; BRUn, I.R. Derecho procesal penal. Pamplona: Gobierno de Navarra, 2006.

Soltoski, Andréia. A prisão preventiva como ultima ratio das medidas processuais. Justiça e Sistema Criminal, v. 2, n. 3, p. 196, Curitiba: FAE Centro Universitário, jul.-dez. 2010.

SouZA, Artur César de. Justo processo ou justa decisão. RePro, n. 196, p. 469, São Paulo, RT, 2011.

SouzA, Carolina Yumi de. Cooperação jurídica internacional em matéria penal: considerações práticas. RBCCrim, p. 297, São Paulo, RT, 2008.

StElla, Claudia. As implicações do aprisionamento materno na vida dos(as) filhos(as). RBCCrim, n. 34, São Paulo, RT, abr. 2001.

SUANNES, Adauto. Os fundamentos éticos do devido processo penal. 2 ed. Ver e atual. São Paulo: Editora Revista dos Tribunais, 2004.

TuCCI, Rogério Lauria. Direitos e garantias individuais no processo penal brasileiro. 3 . ed. São Paulo: RT, 2009.

URANI, Marcelo Fernadez. (Re)pensando as prisões cautelares com Elio Fazzalari. In: FAYet JÚNIOR, Ney; MAYA, André Machado (coords.). Ciências penais: perspectivas e tendências da contemporaneidade. Curitiba: Juruá Editora, 2011.

VERNET, Joseph. I sostitutivi del cárcere preventivo. Rivista di Criminologia e Diritto Criminale, anno LXXV, Dott. A. Giuffrè Editore, 1970.

ZAGREBELSKy, Gustavo. El derecho dúctil. Ley, derechos, justicia. 7. ed. Madrid: Editorial Trotta, 2007.

; MARTINI, Carlo Maria. La exigencia de justicia. Madrid: Miguel Carbonell, 2006.

ZAPATERO, Luis Arroyo. A harmonização internacional do direito penal: ideias e processos. RBCCrim, n. 84, p. 49, São Paulo, RT, mai. 2010.

ZAVASCKI, Teori Albino. Cooperação jurídica internacional e a concessão de exequatur. RePro, n. 183, p. 8, São Paulo, RT, 2010.

ZILli, Marcos Alexandre Coelho. Ainda que tardia, que venha a liberdade: breve panorama sobre a prisão cautelar no direito brasileiro. RBCCrim, n. 85, São Paulo, RT, jul. 2010. 
WALDROM, Jeremy. Foreign law and the modern ius gentium. Harvard Law Review, v. 119, p. 129,

WARren, S. D.; BrandeIS, L. D. The right to privacy. Harvard Law Review, v. IV, n. 5, Dec. 1890. 